\title{
MONITORAMENTO DAS ÁGUAS DO RIO MOSSORÓ/RN, NO PERÍODO DE ABRIL/2005 A JULHO/2006
}

\author{
Valdiery Silva de Araújo \\ Tecnólogo em Controle Ambiental, CEFET-RN.
}

Jerônimo Pereira dos Santos

Geólogo, Mestre em Geoprocessamento. Professor do CEFET-RN. jerônimo@,cefetrn.br

\section{André Luis Calado Araújo}

Engenheiro Civil, Mestre e PhD em Engenharia Sanitária. Professor do CEFET-RN. acalado@cefetrn.br

\section{RESUMO}

O trabalho tem por objetivo realizar uma comparação da qualidade físico-química e microbiológica entre três pontos de monitoramento do Rio Mossoró: Barragem do Genésio (utmx-681464; utmy-9422890), Barragem Central (utmx-683867; utmy-9425546) e Barragem Passagem de Pedra (utmx-690119; utmy-9429968) no município Mossoró/RN. Os pontos encontram-se sob diferentes influências antrópicas e foram monitorados no período de abril/2005 a julho/2006, sendo analisadas as seguintes variáveis: coliformes totais, coliformes termotolerantes, oxigênio dissolvido (OD), demanda química de oxigênio (DQO), nitrato, zinco, cobre, chumbo, cromo, mercúrio, cádmio, pH, temperatura, cor e turbidez. Além dessas análises, ainda houve outras variáveis como nitrogênio total, sólidos totais, fósforo total, demanda bioquímica de oxigênio (DBO) que somadas as citadas serviram de base de cálculo para o Índice de Qualidade de Águas IQA da primeira coleta de 2007 (10 de jan.). Embora à sazonalidade climática altere as concentrações dos contaminantes por intermédio da variação do volume do rio, a Barragem do Genésio, situada a montante da cidade, apresenta-se como o ponto de menor concentração das variáveis analisadas. A Barragem Central, localizada no centro da cidade, responde pelas maiores concentrações analisadas durante o período, resultado do lançamento de esgotos domésticos e industriais sem o devido tratamento. Outra característica observada nesse ponto é a proliferação anormal de macrófitas e algas, indicando o processo da eutrofização. Em termos de Índice de Qualidade das Águas, conclui-se que há diminuição da qualidade no sentido montante-jusante, embora o IQA da Barragem Central e Passagem de Pedra sejam semelhantes.

PALAVRAS-CHAVE: Rio Mossoró. Monitoramento. Índice de Qualidade das Águas. Eutrofização. Autodepuração.

\section{WATER QUALITY MONITORING ON MOSSORÓ RIVER - RN: ABRIL/2005 -} JULY/2007

\section{ABSTRACT}

The present study intends to realize a comparison of chemical-physical and biological water quality between three points of the River Mossoró: Barragem do Genésio (utmx- 
681464; utmy-9422890), Barragem Central (utmx-683867; utmy-9425546) e Barragem Passagem de Pedra (utmx-690119; utmy-9429968), all located in the city of Mossoró/RN. These points are into different entropic influences and were monitored from april/2005 to july/2006. The factors analyzed were, total coliforms, fecal coliforms, dissolvid oxygen (DO), chemical oxygen demand (COD), nitrate, zinc, copper, lead, chromium, mercury, cadmium, $\mathrm{pH}$, temperature, color, turbidity. Beyond these, there were also analyzed total nitrogen, total solids, total phosphorus, biochemical oxygen demand (BOD) to match with the first ones as basis to calculate the water quality index - WQI from the first sampling of 2007 (jan $10^{\text {th }}$ ). Despite the climatic seasonality, diminution of river volume alters the contaminants concentrations, the Barragem do Genésio point, located amount the city, shows the minor values to the variables analyzed. The Barragem Central, located near the center of the city, responds for the higher concentrations, result of non-treated domestic and industrial sewage throwing. Another characteristic observed to this point is the abnormal proliferation of macrofit and seaweed, indicating an eutrophic process. To the WQI the conclusion is that a quality decrease from amount to the mouth route, considering the similarity of Barragem Central and Barragem Passagem de Pedra WQIs.

Key words: Mossoró River. Monitoring. Water Quality Index. Eutrophization. Self depuration. 


\section{MONITORAMENTO DAS ÁGUAS DO RIO MOSSORÓ/RN, NO PERÍODO DE ABRIL/2005 A JULHO/2006}

\section{INTRODUÇÃO}

A água é essencial para a vida e tem um papel vital no funcionamento apropriado dos ecossistemas terrestres. O planeta Terra é o único planeta do sistema solar que tem água nos três estados (sólido, líquido e gasoso), e as mudanças de estado físico da água no ciclo hidrológico são fundamentais e influenciam os processos biogeoquímicos nos ecossistemas terrestres e aquáticos.

Este recurso é indispensável à homeostase ambiental. Devido às características intrínsecas, ela é utilizada em diversos âmbitos: 1. econômicos: irrigação agrícola, abastecimento industrial. 2. sociais: balneabilidade, abastecimento público. 3. tecnológicos: produção de energia elétrica bem como a preservação do ecossistema aquático.

Na superfície do nosso planeta $75 \%$ da área são cobertos por água, sendo $97 \%$ salgada, e apenas 3\% doce. Contudo, do percentual total da água doce existente, a maior parte 2,2\% encontra-se sob a forma de gelo nas calotas polares e geleiras, e em menor volume sob a forma líquida $0,8 \%$ - representada pelas fontes subterrâneas $97 \%$ e superficiais $3 \%$. Já os rios e lagos, que são nossas principais formas de abastecimento, correspondem a apenas $0,01 \%$ desse percentual, aproximadamente. (SPERLING e CETESB apud ARAÚJO et al, 2006).

Sua poluição tem um impacto sério em todas as criaturas vivas, e pode negativamente afetar o uso da água para beber, necessidades da casa, recreação, pesca, transporte e comércio.

É fato a associação de doenças (verminoses, doenças de pele, gastrenterite, hepatite, cólera, febre tifóide) por veiculação hídrica. O controle dessa relação possibilita uma sensível melhoria nas condições de vida da sociedade, demonstrando que não se pode fazer saúde pública sem um adequado controle de qualidade das águas.

Apesar da necessidade deste recurso para a sobrevivência e para o desenvolvimento econômico, o homem continua degradando o meio ambiente (solo, ar, água, seres bióticos). Essa degradação aumenta com o crescimento populacional e industrial observados nas últimas décadas, tendo na falta de recursos financeiros um agravante do problema, pois sem recursos dificultam a aplicação de medidas preventivas e corretivas.

De acordo com Viana (2001, apud ARAÚJO et al 2006):

Os resíduos orgânicos, minerais, tóxicos, mistos e atômicos são as principais fontes de poluição originárias das atividades do progresso do homem, particularmente nas indústrias. Em âmbito nacional, o principal problema de qualidade das águas é o lançamento de esgotos domésticos, pois apenas $47 \%$ dos 
municípios brasileiros possuem rede coletora de esgoto, e somente $18 \%$ recebem algum tratamento.

Segundo o IBGE (2005), o Rio Grande do Norte possui 52.796,791 km² de área, 167 municípios, e estimou-se 3.003.087 habitantes em 2005. Comparando-se ao Censo 2000 (população estimada em 2.777.509 habitantes), em cinco anos houve um crescimento aproximado de 7,51\%. De acordo com SILVA (2004, apud FERREIRA, 2006), menos de $20 \%$ da população do estado dispõe de serviço de coleta de esgotos sanitários.

Em Mossoró (Figura 1), município do Rio Grande do Norte, a população corresponde a 213.841 habitantes e possui extensão territorial de $2.110 \mathrm{~km}^{2}$ (IBGE 2005). Em termos de saneamento, o município detém uma rede de saneamento básico da cidade que atende a $55 \%$ da população mossoroense, diz o gerente de Infra Estrutura Municipal Yuri-Tasso (O MOSSOROENSE, 2007).

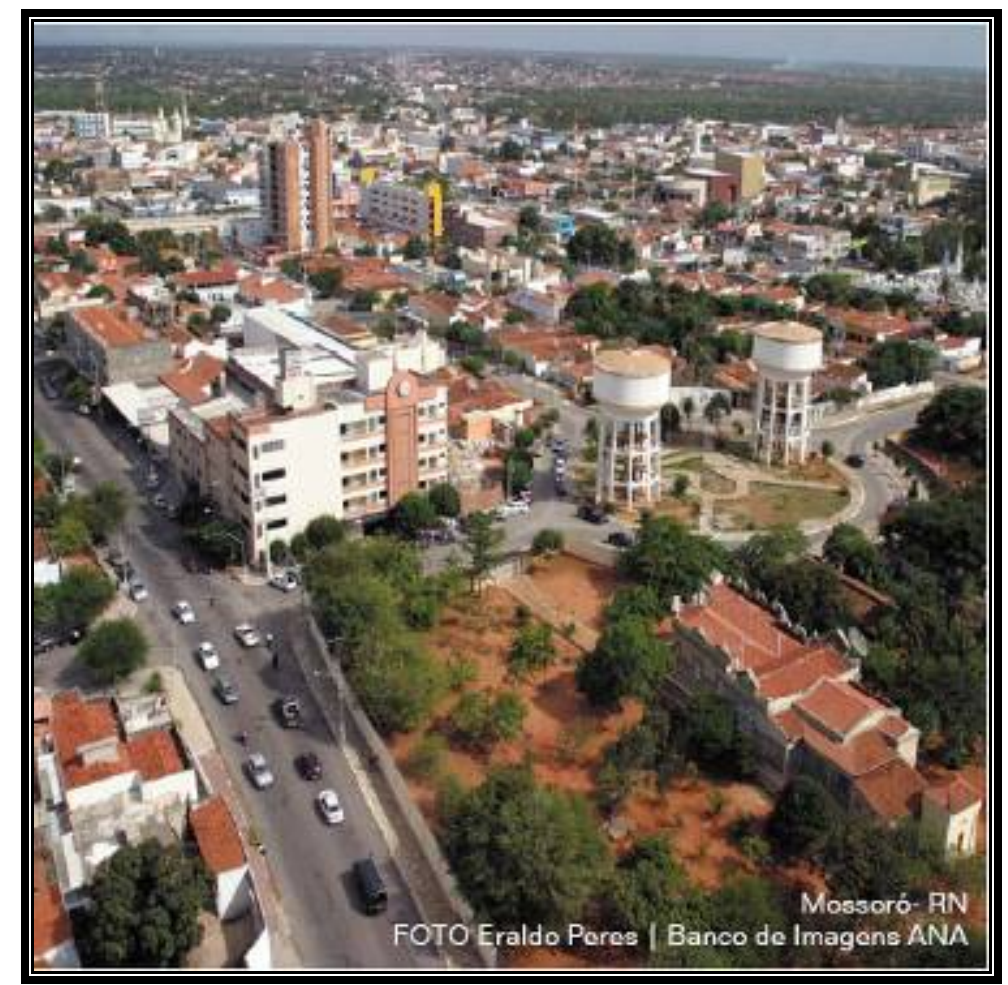

Figura 1 - Imagem aérea da cidade de Mossoró/RN.

Fonte: Atlas Nordeste - Abastecimento Urbano de Água (ANA - Agência Nacional das Águas).

Relativo aos recursos hídricos, o município encontra-se totalmente inserido nos domínios da bacia hidrográfica Apodi-Mossoró (Figura 3), sendo banhado pela sub-bacia do Rio Mossoró (Figura 2), que o atravessa na direção SSW-NE, tendo como principais tributários: a N, o córrego Gangorra; a S, o Rio do Carmo, os riachos: do Bonsucesso, do Nogueira, Grande, do Inferno, Fundo e Olho d'água, além do córrego do Bastião; a E, os riachos: da Suçuarana, Poço dos Bois, Xique xique, Passagem Velha, São Raimundo, Pai Antônio e o Córrego Jerimum; a W, os riachos Campo do Junco, Grande, Cabelo Negro e córrego do Virgílio. Os principais corpos de acumulação são os açudes públicos: Barragem do Genésio, Barragem Passagem de Pedras, Barragem de Baixo, Barragem do Saco, Barragem Lagoa de Paus, Barragem Central e os açudes comunitários: Barragem Santana, Dos Pintos e Favela (CPRM - Serviço Geológico do Brasil, 2005). 




Figura 2 - Imagem do Rio Mossoró cortando o município de Mossoró. Fonte (adaptado): Google Earth 


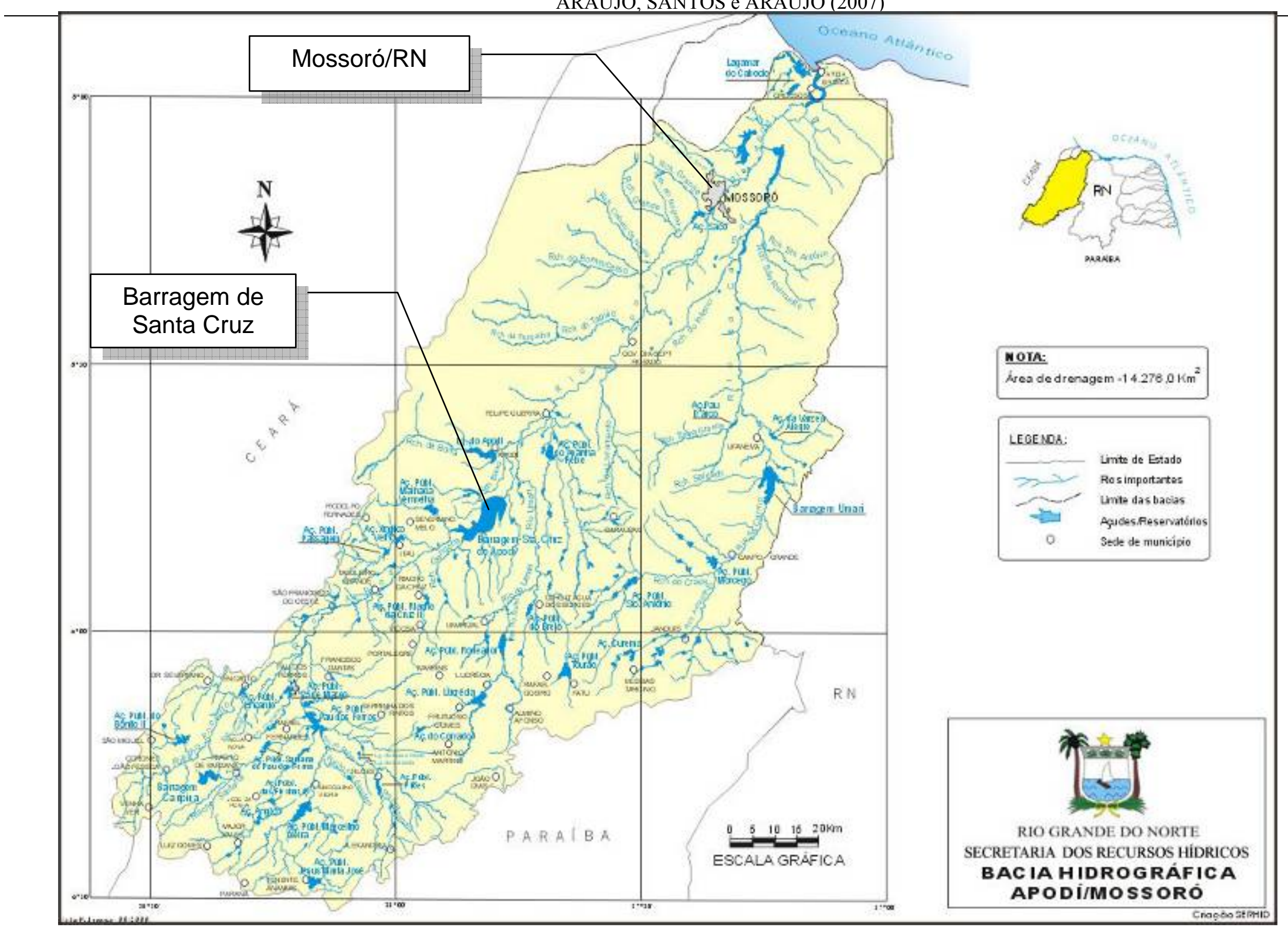

Figura 3 - Bacia Hidrográfica do Apodi-Mossoró.

Fonte: Secretaria de Estado do Meio Ambiente e dos Recursos Hídricos - SEMARH 
Com a intenção de evitar as enchentes que deixavam as vazantes submersas, a população, na década de oitenta, resolveu canalizar o rio. O desvio fez com que o rio começasse a secar, e em 1905 o rio Mossoró parou de correr por trinta meses. Por isso, em 1917 o engenheiro Pedro Ciarlini foi chamado para construir obras contra as secas, entre as quais barragens no rio Mossoró. Foram construídas sete barragens espalhadas ao longo do rio, assim o rio não mais secava, mas a qualidade da água represada não atendia as condições de potabilidade.

A construção de barragens deve ser elaborada levando em consideração as nuances locais. Os ambientes hídricos podem ser classificados em lóticos (rios) e lênticos (lagos). E a construção de barragens promove a transformação de meios lóticos em lênticos o que provoca mudanças nas características físico-químicas das águas que sofrem alterações bruscas, criando um novo ecossistema que, aos poucos, retorna a seu equilíbrio.

Atualmente, o problema das enchentes foi sanado a partir do controle de vazão do rio por intermédio da Barragem de Santa Cruz que fica a montante do município. O sítio barrável está localizado sobre o rio Apodi, na Bacia do Apodi-Mossoró, no boqueirão denominado Santa Cruz, distante $18 \mathrm{~km}$ a montante da sede do município de Apodi/RN.

\subsection{OBJETIVOS}

Os objetivos do presente trabalho concernem as seguintes nuances:

- Apresentar e comparar com as preconizações da Resolução CONAMA 357, de 17 de março de 2005, as variáveis físico-químicas e microbiológicas (coliformes totais, coliformes termotolerantes, $\mathrm{pH}$, turbidez, cor, temperatura, oxigênio dissolvido, nitrato, zinco, cobre, chumbo, cromo, mercúrio, cádmio) resultantes de amostras coletadas no Rio Mossoró.

- Calcular a qualidade das águas do Rio Mossoró por intermédio do Índice de Qualidade de Águas - IQA, nos três pontos de coleta da última amostragem realizada, 10 de janeiro de 2007.

\section{CONSIDERAÇÕES TEÓRICAS}

\subsection{AUTODEPURAÇÃO}

Os ecossistemas desenvolveram maneiras sofisticadas para processar e armazenar os produtos naturais da excreção como os sedimentos, nutrientes, metais pesados, e bactérias.

A água é o meio principal de transporte desses materiais na maioria dos ecossistemas. Cada rio ou lago possui, até certo ponto, uma capacidade natural de receber poluentes. Essa capacidade de neutralização da matéria poluidora através dos processos de diluição, sedimentação e estabilização química é denominada autodepuração. O equilíbrio está diretamente relacionado à capacidade do corpo d'água de assimilar os lançamentos, não conflitando com a sua utilização. Nos cursos d'água poluídos ocorre uma transformação gradual dos componentes orgânicos em sais minerais e gás carbônico, restabelecendo-se lentamente a limpidez das águas naturais (BRANCO, 1986 apud COSTA et al, 2003).

A solução adotada para o despejo de esgoto doméstico é o lançamento, na maioria das vezes sem tratamento prévio, dos efluentes em corpos d'água; a poluição de um rio devido ao 
lançamento de efluentes não fica restrita ao trecho do rio onde ocorre o lançamento, mas comprometerá toda a sua bacia hidrográfica, bem como a sua região estuarina onde lança suas águas. A capacidade de autodepuração do corpo d'água é bastante afetada pelas variações de vazão presentes nos lançamentos desses efluentes. Se a mesma quantidade de matéria orgânica é lançada diluída é de se esperar uma melhor resposta do corpo d'água (CUNHA \& FERREIRA, op cit).

\title{
2.2 EUTROFIZAÇÃO
}

O Estado Trófico (Tabela 2) é uma classificação de corpos d'água em diferentes graus de trofia, ou seja, caracteriza a qualidade da água quanto ao enriquecimento por nutrientes e seu efeito relacionado ao crescimento excessivo das algas, ou o potencial para o crescimento de macrófitas aquáticas.

Tabela 1 - Possíveis estados eutróficos de corpos aquáticos

Estado Trófico $\quad$ Especificação

Oligotrófico

Corpos de água limpos, de baixa produtividade, em que não ocorrem interferências indesejáveis sobre os usos da água.

Mesotrófico

Corpos de água com produtividade intermediária, com possíveis implicações sobre a qualidade da água, mas em níveis aceitáveis, na maioria dos casos.

Eutrófico

Corpos de água com alta produtividade em relação às condições naturais, de baixa transparência, em geral afetados por atividades antrópicas, em que ocorrem alterações indesejáveis na qualidade da água e interferências nos seus múltiplos usos.

Corpos de água afetados significativamente pelas elevadas concentrações de matéria orgânica e nutrientes, com comprometimento acentuado nos seus usos, podendo inclusive estarem associados a episódios florações de algas e de mortandade de peixes e causar conseqüências indesejáveis sobre as atividades pecuárias nas regiões ribeirinhas.

Fonte (adaptado): CETESB, 2007.

Para CARVALHO (2004):

\begin{abstract}
A eutrofização de cursos d'água (rios, lagos ou represas) é o processo que resulta num aumento de nutrientes essenciais para o fitoplâncton (algas) e plantas aquáticas superiores, principalmente nitrogênio, fósforo, potássio, carbono e ferro. Como desencadeadores da eutrofização natural podem-se citar os nutrientes trazidos pelas chuvas e águas superficiais, que erodem e lavam a superfície terrestre. Mas o homem aprendeu a reproduzir o processo natural e assim surgiu a eutrofização artificial, também chamada de eutrofização acelerada ou antrópica.

Quando controlada, para fins de piscicultura, a reprodução das condições eutróficas pode ser desejável, pois permite a multiplicação de algas que servem de alimento para os microcrustáceos, que por sua vez constituem o alimento das larvas da maioria dos peixes. Nas últimas décadas, entretanto, a eutrofização natural tem sido agravada pela eutrofização artificial decorrente do lançamento, nos corpos d'água, de efluentes domésticos e industriais, assim como de água resultante de drenagem de áreas cultivadas com adubos químicos.
\end{abstract}

De acordo com ESTEVES e TUNDISI (1986, apud VALENTE et al 1997), a eutrofização causa diversos prejuízos, tais como: 
- O aumento em demasia da quantidade de plantas aquáticas submersas (por exemplo, algas) e flutuantes (macrófitas) que podem dificultar a navegação de barcos.

- A liberação de toxinas por alguns tipos de algas;

- Sabor na água de abastecimento;

- O excesso de plantas aquáticas, quando morrem vão para o fundo e entram em decomposição, provocando o consumo de grandes quantidades de oxigênio. Podem ainda gerar gases tóxicos, corrosivos e de mau cheiro.

- Em geral as macrófitas liberam o oxigênio da fotossíntese para fora do corpo d'água, e quando em excesso provocam sombreamento evitando a fotossíntese de algas. Tornam o meio propício para a deposição de larvas de insetos causadores de doenças. Adsorvem e absorvem metais pesados e nutrientes da água - o que poderia ser benéfico se estas plantas fossem tiradas do meio aquático, no entanto isso raramente ocorre por falta de local adequado para dispor as mesmas, e a presença de metais pesados impede a sua adição no solo para uso agrícola, pois isto causaria contaminação do mesmo.

- Alteração da acidez da água $(\mathrm{pH})$, pois consome gás carbônico pela absorção fotossintética (varia do dia para a noite). A alteração na acidez pode causar a morte de determinadas formas de vida aquáticas.

\subsection{INDICADORES DE OXIGÊNIO}

O oxigênio dissolvido (OD) é um indicador da concentração de oxigênio dissolvido na água em $\mathrm{mg} / \mathrm{L}$. O oxigênio é um gás pouco solúvel em água e a sua solubilidade depende da pressão (altitude), temperatura e sais dissolvidos, normalmente a concentração de saturação está em torno de $8 \mathrm{mg} / \mathrm{L}$ a $25^{\circ} \mathrm{C}$ entre 0 e $1.000 \mathrm{~m}$ de altitude.

O oxigênio dissolvido, uma variável ambiental clássica, pode em sua ausência afetar significativamente a biota aquática. De um modo geral e simplificado, com base nos critérios de qualidade para oxigênio dissolvido publicados pela Agência de Proteção Ambiental dos Estados Unidos (EPA), as faixas de concentração de oxigênio dissolvido com as respectivas comunidades aquáticas que podem suportar tais níveis de oxigênio dissolvido são: de 0 a 2 $\mathrm{mg} / \mathrm{L}$ é insuficiente para manter a vida aquática, de 2 a $4 \mathrm{mg} / \mathrm{L}$ somente poucas espécies de peixes podem sobreviver, de 4 a $7 \mathrm{mg} / \mathrm{L}$ é aceitável para peixes de águas quentes e de 7 a 11 $\mathrm{mg} / \mathrm{L}$ é ideal para peixes de águas frias (SILVA \& JARDIM, 2006).

Quando a carga dos esgotos lançados excede a capacidade de autodepuração do corpo de água, o rio fica sem oxigênio, provocando problemas estéticos e liberação de odor e impedindo a existência de peixes e outros seres aquáticos, os peixes morrem não por toxicidade, mas por asfixia. Todos os organismos vivos dependem de uma forma ou de outra do oxigênio para manter os processos metabólicos de produção de energia e de reprodução. A quantidade de alimento (esgoto ou outros despejos orgânicos assimiláveis) lançada ao corpo d'água deve ser proporcional à sua vazão ou ao seu volume, isto é, à sua disponibilidade de oxigênio dissolvido.

\section{Para VALENTE et al (1997):}

- A demanda bioquímica de oxigênio (DBO) é um indicador que determina indiretamente a concentração de matéria orgânica biodegradável através da demanda de oxigênio exercida por microrganismos através da respiração. A DBO é um teste padrão, realizado a uma temperatura constante de $20^{\circ} \mathrm{C}$ e durante um período de incubação também fixo, 5 dias. É uma medida que procura retratar em laboratório o fenômeno que acontece no corpo 
d'água. Assim uma amostra é coletada em duplicata, e em uma das amostras é medido o oxigênio dissolvido após a coleta; o oxigênio da outra amostra é medido após 5 dias, período em que a amostra fica em uma incubadora a uma temperatura de $20^{\circ} \mathrm{C}$. A diferença de concentração de oxigênio representa a demanda bioquímica de oxigênio (oxigênio consumido para oxidar a matéria orgânica via respiração dos microrganismos). É um indicador estimativo, já que as condições: turbulência das águas, aeração e insolação etc. não são consideradas.

- A demanda química de oxigênio (DQO) é um indicador de matéria orgânica baseado na concentração de oxigênio consumido para oxidar a matéria orgânica, biodegradável ou não, em meio ácido e condições energéticas por ação de um agente químico oxidante forte. Esta técnica apenas estima a concentração de matéria orgânica em termos de oxigênio consumido já que nos corpos d'águas as condições não são tão energéticas, além do fato de que algumas espécies inorgânicas, tais como nitritos, compostos reduzidos de enxofre e substâncias orgânicas - como hidrocarbonetos aromáticos, compostos alifáticos de cadeia aberta e piridinas - não são oxidadas. A principal vantagem da DQO é a rapidez, pouco mais de duas horas, enquanto que a DBO leva 5 dias.

\subsection{TEMPERATURA - T}

Variações de temperatura são parte do regime climático normal, e corpos de água naturais apresentam variações sazonais e diurnas, bem como estratificação vertical. A temperatura superficial é influenciada por fatores tais como latitude, altitude, estação do ano, período do dia, taxa de fluxo e profundidade. A elevação da temperatura em um corpo d'água geralmente é provocada por despejos industriais (indústrias canavieiras, por exemplo) e usinas termoelétricas (CETESB, 2007).

A temperatura tem um efeito direto sobre a taxa ou cinética das reações químicas, nas estruturas protéicas e funções enzimáticas dos organismos, portanto as atividades biológicas dos organismos aquáticos sofrem constantes alterações decorridas das freqüentes modificações comportamentais do meio, como quando da elevação da temperatura, que no caso os obriga a um consumo maior de oxigênio, já reduzido em sua concentração na água, pelo próprio processo físico.

\subsection{TURBIDEZ - Tur}

É a medida da dificuldade de um feixe de luz atravessar uma certa quantidade de água. A turbidez é causada por matérias sólidas em suspensão (silte, argila, colóides, matéria orgânica, etc.). A turbidez é medida através do turbidímetro, comparando-se o espalhamento de um feixe de luz ao passar pela amostra com o espalhamento de um feixe de igual intensidade ao passar por uma suspensão padrão. Quanto maior o espalhamento maior será a turbidez. Os valores são expressos em Unidade Nefelométrica de Turbidez (UNT). A cor da água interfere negativamente na medida da turbidez devido à sua propriedade de absorver luz. Segundo a OMS (Organização Mundial da Saúde), o limite máximo de turbidez em água potável deve ser 5 UNT. As águas subterrâneas normalmente não apresentam problemas devido ao excesso de turbidez. Em alguns casos, águas ricas em íons Fe, podem apresentar uma elevação de sua turbidez quando entram em contato com o oxigênio do ar.

Esse parâmetro é aumentado quando há erosão das margens dos rios em estações chuvosas que exige manobras operacionais, como alterações nas dosagens de coagulantes e auxiliares nas estações de tratamento de águas. 
A turbidez, por si só, não caracteriza poluição na água. A água turva nem sempre está poluída, pois ela pode estar com certa turbidez pela presença maior de partículas dissolvidas orgânicas ou não, porém dentro da dinâmica natural biofisicoquímica daquele meio ou ambiente. No entanto, águas que recebam fontes de "poluição" que lançam material fino de origem orgânica ou mineral apresentam-se com maior turbidez (PÁDUA, 2003).

\subsection{POTENCIAL HIDROGENIÔNICO - pH}

$\mathrm{O}$ valor do $\mathrm{pH}$ é um número aproximado entre 0 e 14 que indica se uma solução é ácida $(\mathrm{pH}<7)$, neutra $(\mathrm{pH}=7)$, ou básica/alcalina $(\mathrm{pH}>7)$. $\mathrm{Na}$ água o valor desse parâmetro depende de sua origem e características naturais, mas pode ser alterado pela introdução de resíduos; $\mathrm{pH}$ baixo torna a água corrosiva; águas com $\mathrm{pH}$ elevado tendem a formar incrustações nas tubulações; a vida aquática depende do $\mathrm{pH}$, sendo recomendável $\mathrm{pH}$ na faixa de 6 a 9. De acordo com a Portaria 518/04 do Ministério da Saúde a faixa recomendada de pH na água distribuída é de 6,0 a 9,5.

A influência do $\mathrm{pH}$ sobre os ecossistemas aquáticos naturais dá-se diretamente devido a seus efeitos sobre a fisiologia das diversas espécies. Também o efeito indireto é muito importante podendo, determinadas condições de $\mathrm{pH}$ contribuírem para a precipitação de elementos químicos tóxicos como metais pesados; outras condições podem exercer efeitos sobre as solubilidades de nutrientes (CETESB, 2007).

\subsection{NITRATO $-\mathrm{NO}_{3}{ }^{-}$}

O nitrato ocorre naturalmente no solo que contem bactérias fixadoras de nitrogênio, vegetais em decomposição, efluentes sépticos e esterco de animais. Outras fontes incluem fertilizantes nitrogenados e os gases emitidos pela indústria e pelos automóveis (MANASSARAM et al, 2007).

O esgoto doméstico bruto apresenta também altas concentrações de nitrogênio orgânico, com valores que podem variar de 15,0 a $30,0 \mathrm{mgN} / \mathrm{L}$. Este nitrogênio é primeiramente mineralizado e posteriormente oxidado, sendo convertido inicialmente na amônia e depois em nitrito e nitrato; vários autores têm apontado para as doenças causadas pela ingestão de água com altas concentrações de nitrato, através das águas de abastecimento (CUNHA \& FERREIRA, 2006).

O nitrato pode ser convertido a nitrito pela ação de algumas enzimas da saliva e bactérias específicas. $\mathrm{O}$ excesso de nitrito em águas representa um potencial risco para a saúde, pois pode causar a meta-hemoglobinemia ("síndrome do bebê-azul") em recém-nascidos e mesmo em adultos com particular deficiência enzimática. A quantidade de nitrito deve também ser controlada devido à possível formação de nitrosaminas carcinogênicas, pela sua reação com aminas secundárias presentes no estômago de mamíferos (RAMOS et al, 2006).

\subsection{COLIFORMES TOTAIS - CT E TERMOTOLERANTES - CTer}

O grupo de bactérias determinado coliformes totais são aquelas que não causam doenças, visto que habitam o intestino de animais mamíferos, inclusive o homem. São considerados os principais indicadores de contaminação fecal. O grupo coliforme é formado por um número de bactérias que inclui os gêneros Klebsiella, Escherichia, Serratia, Erwenia e Enterobactéria. Todas as bactérias coliformes são gram-negativas manchadas, de hastes não esporuladas que 
estão associadas com as fezes de animais de sangue quente e com o solo. As bactérias coliformes fecais reproduzem-se ativamente a $44,5^{\circ} \mathrm{C}$ e são capazes de fermentar o açúcar (CETESB, 2007).

O uso da bactéria coliforme fecal para indicar poluição sanitária mostra-se mais significativo que o uso da bactéria coliforme "total", porque as bactérias fecais estão restritas ao trato intestinal de animais de sangue quente. A determinação da concentração dos coliformes assume importância como parâmetro indicador da possibilidade da existência de microorganismos patogênicos, responsáveis pela transmissão de doenças de veiculação hídrica, tais como febre tifóide, febre paratifóide, disenteria bacilar e cólera.

\title{
2.9 METAIS PESADOS
}

Dentre as várias formas de contaminação do meio ambiente resultante das diversas atividades industriais e agrícolas, a contaminação da água com metais pesados tem sido uma das que tem trazido mais preocupação aos pesquisadores e órgãos governamentais envolvidos no controle de poluição. É que a água, além de ser um dos mais importantes fatores da preservação da vida em vias de se tornar escassa no mundo, está sendo contaminada com o despejo de rejeitos industrial-urbanos e várias outras atividades humanas. (OLIVEIRA et al, 2001)

Para ALLOWAY (1993, apud MARSOLA et al, 2005):

\begin{abstract}
São denominados metais pesados todos aqueles que apresentam massa específica superior a $6 \mathrm{~g} / \mathrm{cm}^{-3}$, poluem o meio ambiente e podem provocar diferentes níveis de danos à biota. Os principais metais pesados são: $\mathrm{Ag}, \mathrm{Cd}, \mathrm{Co}, \mathrm{Cr}, \mathrm{Cu}, \mathrm{Hg}, \mathrm{Ni}, \mathrm{Pb}, \mathrm{Sb}$, e $\mathrm{Zn}$, aos quais poderão, futuramente, ser incluídos outros metais, conforme a contaminação ambiental antropogênica. Os metais, pesados são encontrados naturalmente no solo em concentrações inferiores às consideradas tóxicas para diferentes organismos vivos.
\end{abstract}

\subsubsection{Cádmio - Cd}

O cádmio é um elemento relativamente raro. Sua abundância na litosfera estima-se em cerca de $0,5 \mathrm{ppm}$. Não existem minerais que contenham cádmio em quantidades comerciais, obtendo-se sempre como produto secundário da extração de outros elementos. $\mathrm{O}$ mineral mais comum é a greenockite, rica em sulfureto de cádmio, que ocorre associada a sulfureto de zinco. Quase todos os depósitos de zinco contêm cádmio, apesar de a concentração deste não ultrapassar cerca de $1 \%$.

Segundo EPA (Environmental Protection Agency, 2006), a maior utilização do cádmio é primeiramente em operações de revestimento de metal, abrangendo equipamentos de transporte, fotografia, fósforo da televisão. É usado também em baterias níquel-cádmio e em pigmentos.

A EPA (op. cit.) aponta que o cádmio pode causar potencialmente os seguintes efeitos de saúde quando o individuo é exposto ao metal em períodos de tempo relativamente curtos: náusea, vômitos, diarréia, grampos do músculo, distúrbios sensoriais, ferimento de fígado, convulsões, choque e falha renal. Quanto a doenças crônicas, o cádmio tem o potencial de comprometer os seguintes órgãos: os rins, o fígado, os ossos e o sangue. 


\title{
2.9.2 Cromo - Cr
}

O cromo é um metal que ocorre no ecossistema como resultado da intemperização do material de origem dos solos e que pode ser introduzido através de deposições de resíduos de origem industrial como curtumes e siderurgia. A disposição no solo pode causar uma significante poluição de aqüíferos e do próprio solo quando os efluentes dessas indústrias são depositados ou utilizados na irrigação e/ou como insumo agrícola (CASTILHOS et al, 2001).

Sua maior utilização está em ligas do metal tais como o aço inoxidável, revestimentos protetores no metal, fita adesiva magnéticas, soldagens, curtume, pigmentos para pinturas, cimento, papel, borracha, e outros materiais (EPA, 2006).

Cuidados especiais são necessários tanto na manipulação durante o processo industrial como no tratamento dos resíduos. Os resíduos possuem alto poder de contaminação, quando não são convenientemente tratados e simplesmente abandonados em corpos d'água, aterros industriais ou mesmo lixeiras clandestinas. Com facilidade, o cromo atinge o lençol freático ou mesmo reservatórios ou rios que são as fontes de abastecimento de água das cidades. Se o resíduo é degradado no solo, o cromo permanece e pode ser absorvido por plantas que posteriormente servirão de alimento diretamente ao homem ou a animais, podendo por este caminho também atingir o ser humano (GIANNETI et al, 2006).

Cromo (VI) é um carcinógeno humano reconhecido e muitos trabalhadores são expostos a este composto químico. A fumaça contendo este elemento químico causa uma variedade de doenças respiratórias, incluindo câncer. $\mathrm{O}$ contato da pele com compostos de cromo causa dermatite alérgica e, mais raramente, pode provocar ulcerações na pele formando cicatrizes e até perfurações do septo nasal (GIANNETI op. cit.).

\subsubsection{Mercúrio - Hg}

De acordo com SIQUEIRA et al, 2005:

\begin{abstract}
No ambiente aquático, o mercúrio é mais comumente encontrado no estado mercúrio (II) e o seu destino, uma vez lançado, é dominado pela adsorção rápida ao material orgânico e inorgânico solúvel e particulado e, em seguida, pela floculação, precipitação e pelo acúmulo final no sedimento de fundo (Moore \& Ramamoorthy, 1984). O mercúrio é considerado o mais nocivo e é o único metal pesado que, comprovadamente, sofre biomagnificação ao longo da cadeia trófica, sofrendo, ainda, eficiente organificação, atingindo a sua forma mais tóxica (metilmercúrio) no sistema aquático (Barrocas \& Wasserman, 1995). De acordo com Moore e Ramamoorthy (1984), esse tipo de dinâmica sugere que a exposição ao mercúrio pode ser potencialmente muito danosa, difícil de ser detectada e de ação muito ampla. Para Lacerda e Menezes (1995), em função das propriedades biogeoquímicas do mercúrio e de seus complexos orgânicos, como metilmercúrio, pode ocorrer uma larga dispersão e uma alta exposição ambiental desse metal nos vários compartimentos.
\end{abstract}

O peixe tem sido apontado como a principal via de intoxicação do ser humano por mercúrio. O mercúrio é transformado em metilmercúrio por ação de bactérias; o peixe absorve o metilmercúrio da água e, também, pela ingestão de organismos aquáticos. Mesmo em regiões com níveis normais de mercúrio na água, podem ser observados níveis altos de mercúrio em peixes, pois ao ser incorporado na cadeia trófica, o mercúrio é biomagnificado e bioacumulado, devido a sua longa meia-vida nos organismos (640 a 1200 dias). No homem, a absorção intestinal do metilmercúrio é maior que $95 \%$ e sua meia-vida biológica para 
eliminação é em torno de 70 dias. Quando é absorvido, acumula-se nos rins, no fígado e no sistema nervoso central (MORGANO et al, 2005).

As manifestações clínicas da intoxicação por mercúrio podem ser agudas ou crônicas. A aguda, devido à ingestão de alimentos contaminados por metilmercúrio, produz um quadro que varia de leve a letal, com vômitos freqüentes, tremores, ataxia, parestesia, paralisia, afonia, cegueira, coma e morte. A intoxicação crônica afeta principalmente o SNC, causando parestesia, ataxia, dificuldade de articular palavras, sensação generalizada de fraqueza, fadiga e incapacidade de concentração, perda de visão e audição, coma e morte. Os efeitos clínicos não são imediatos. No caso de exposição ambiental, o período latente pode chegar a 10 anos e será inversamente proporcional ao nível de exposição. O metilmercúrio tem efeito feto-tóxico, com alterações irreversíveis para o feto, mesmo sem o aparecimento de sintomas na mãe. Os sintomas observados em neonatais e crianças, devido à exposição pré-natal, são: a paralisia cerebral, distúrbios mentais, retardamento do desenvolvimento de várias funções psicomotoras, convulsões, cegueira e má-formação dos ouvidos (MORGANO op. cit.).

\subsubsection{Zinco - Zn}

O zinco é um metal de cor branco-azulada, forma cristalina hexagonal compacta. É encontrado em todo o meio ambiente (ar, água e solo). No corpo humano, que contém de 2 a 3 gramas de zinco, ele é essencial para o bom funcionamento dos sistemas imunológico, digestivo e nervoso, pelo crescimento, controle do diabetes e os sentidos do gosto e do olfato. Mais de 300 enzimas no corpo humano necessitam do zinco para o seu correto metabolismo. É comprovadamente um agente cancerígeno, teratogênico e pode causar danos ao sistema reprodutivo (JESUS, 2001).

Entre os metais não ferrosos o consumo mundial de zinco só é superado pelo alumínio e o cobre. Em alguns campos de aplicação, o alumínio e o plástico apresentam-se como substitutos do zinco (JESUS op. cit.).

\subsubsection{Cobre - Cu}

O cobre ocorre geralmente nas águas, naturalmente, em concentrações inferiores a $20 \mathrm{mg} / \mathrm{L}$. Quando em concentrações elevadas, é prejudicial à saúde e confere sabor às águas. Segundo pesquisas efetuadas, é necessária uma concentração de $20 \mathrm{mg} / \mathrm{L}$ de cobre ou um teor total de $100 \mathrm{mg} / \mathrm{L}$ por dia na água para produzirem intoxicações humanas com lesões no fígado. No entanto, concentrações de $5 \mathrm{mg} / \mathrm{L}$ tornam a água absolutamente impalatável, devido ao gosto produzido. O cobre em pequenas quantidades é até benéfico ao organismo humano, catalisando a assimilação do ferro e seu aproveitamento na síntese da hemoglobina do sangue, facilitando a cura de anemias, entretanto a EPA (2006) encontrou no cobre um potencial para doenças agudas: distúrbio gastrointestinal, náusea e vômitos. O uso de água contaminada sobre muitos anos pode causar danos do fígado ou dos rins.

\subsubsection{Chumbo - Pb}

O chumbo é um elemento de ocorrência natural, encontrado em relativa abundância na crosta terrestre, quase sempre como sulfeto de chumbo, sendo que as maiores fontes geológicas do metal são as rochas ígneas e metamórficas. As suas principais fontes naturais incluem as emissões vulcânicas, o intemperismo das rochas e as emissões provenientes do mar. No entanto, devido à intensa exploração desse metal pelo homem, atualmente é difícil avaliar o 
conteúdo de chumbo originado dessas fontes naturais. O chumbo é o metal pesado mais profuso no ambiente (QUITÉRIO et al, 2006).

Para MOREIRA \& MOREIRA (2004):

Atualmente, o chumbo é um dos contaminantes mais comuns do ambiente, devido às inúmeras atividades industriais que favorecem a sua grande distribuição. Assim, todos os seres humanos têm chumbo em seus organismos como resultado da exposição às fontes exógenas (Saryan e Zenz, 1994). No entanto, este metal não possui nenhuma função fisiológica conhecida no organismo, e seus efeitos tóxicos sobre os homens e animais já são conhecidos há muito tempo por afetarem praticamente todos os órgãos e sistemas do corpo humano (Xie et al., 1998).

A maior parte do chumbo entra no organismo humano pelas vias respiratória e gastrointestinal. Após absorção, o chumbo pode ser encontrado no sangue, tecidos moles e mineralizados (ATSDR, 1999). O sítio primário de armazenamento de $\mathrm{Pb}$ no organismo é o osso, que contém aproximadamente $95 \%$ do conteúdo corpóreo total do metal em adultos, porém o significado toxicológico deste fato só foi entendido recentemente (Sanín et al., 1998).

\subsection{RESOLUÇÃO CONAMA Nº 357, DE 17 DE MARÇO DE 2005.}

A resolução CONAMA 357/2005 dispõe sobre a classificação dos corpos de água e diretrizes ambientais para o seu enquadramento, bem como estabelece as condições e padrões de lançamento de efluentes, e dá outras providências.

Ela preconiza padrões de qualidade de água que servirão de base comparativa com os resultados físico-químico e microbiológico do Rio Mossoró. Neste caso, o rio é classificado como corpo aquático de água doce e essas são classificadas em:

- Classe especial: águas destinadas: ao abastecimento para consumo humano, com desinfecção; à preservação do equilíbrio natural das comunidades aquáticas; e à preservação dos ambientes aquáticos em unidades de conservação de proteção integral.

- Classe 1: águas que podem ser destinadas: ao abastecimento para consumo humano, após tratamento simplificado; à proteção das comunidades aquáticas; à recreação de contato primário, tais como natação, esqui aquático e mergulho, conforme Resolução CONAMA $\mathrm{n}^{\circ}$ 274, de 2000; à irrigação de hortaliças que são consumidas cruas e de frutas que se desenvolvam rentes ao solo e que sejam ingeridas cruas sem remoção de película; e à proteção das comunidades aquáticas em Terras Indígenas.

- Classe 2: águas que podem ser destinadas: ao abastecimento para consumo humano, após tratamento convencional; à proteção das comunidades aquáticas; à recreação de contato primário, tais como natação, esqui aquático e mergulho, conforme Resolução CONAMA $\mathrm{n}^{\circ} 274$, de 2000; à irrigação de hortaliças, plantas frutíferas e de parques, jardins, campos de esporte e lazer, com os quais o público possa vir a ter contato direto; e à aqüicultura e à atividade de pesca.

- Classe 3: águas que podem ser destinadas: ao abastecimento para consumo humano, após tratamento convencional ou avançado; à irrigação de culturas arbóreas, cerealíferas e forrageiras; à pesca amadora; à recreação de contato secundário; e à dessedentação de animais.

- Classe 4: águas que podem ser destinadas: à navegação; e à harmonia paisagística. 


\subsection{1 ÍNDICE DE QUALIDADE DE ÁGUA - IQA}

O Índice de Qualidade de Água (IQA), desenvolvido pela National Sanitation Foundation com auxilio de especialistas, abrange as interações entre as diversas variáveis mensuradas numa amostra de água. O índice é um primeiro passo para a avaliação da qualidade da água, desde que sejam respeitados critérios amostrais de espaço e tempo das variáveis do sistema a ser estudado.

Os parâmetros contemplados pelo IQA são Coliformes Termotolerantes (CTer), Potencial Hidrogeniônico (pH), Demanda Bioquímica de Oxigênio (DBO), Nitrogênio Total (NT), Fósforo Total (PT), Temperatura (T), Turbidez (Tur), Sólidos Totais (ST) e Oxigênio Dissolvido (OD).

A criação do IQA baseou-se numa pesquisa de opinião junto a especialistas em qualidade de águas, que indicaram os parâmetros a serem avaliados, o peso relativo dos mesmos e a condição com que se apresenta cada parâmetro, segundo uma escala de valores "rating". Dos trinta e cinco parâmetros indicadores de qualidade de água inicialmente propostos, somente nove foram selecionados. Para esses parâmetros, a critério de cada profissional, foram estabelecidas curvas de variação da qualidade das águas, apresentadas anteriormente na Figura 4, de acordo com o estado ou a condição de cada parâmetro (CETESB, 2007).
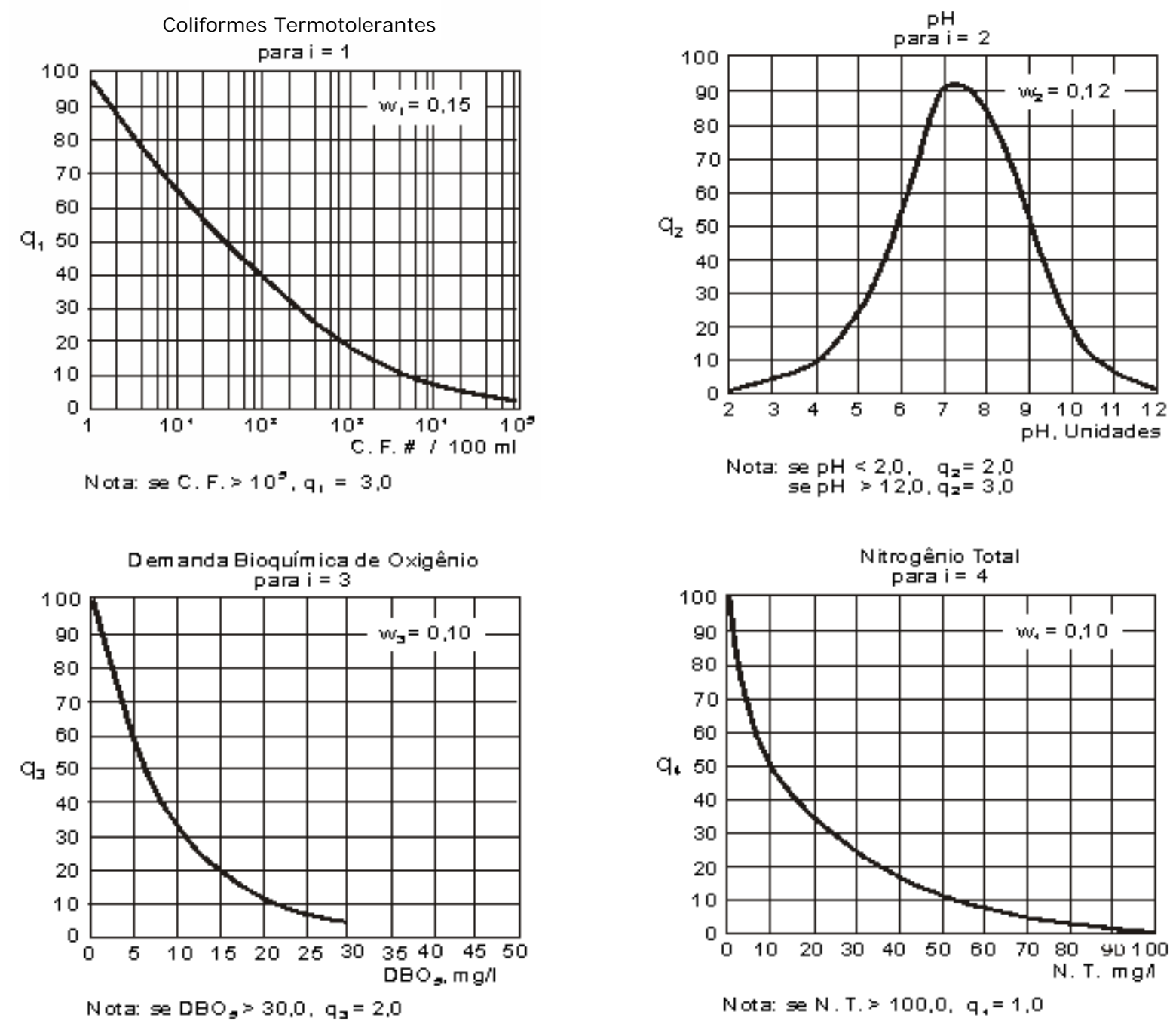

Figura 4 - Curvas de variação da qualidade das águas.

Fonte: CETESB (2007) 


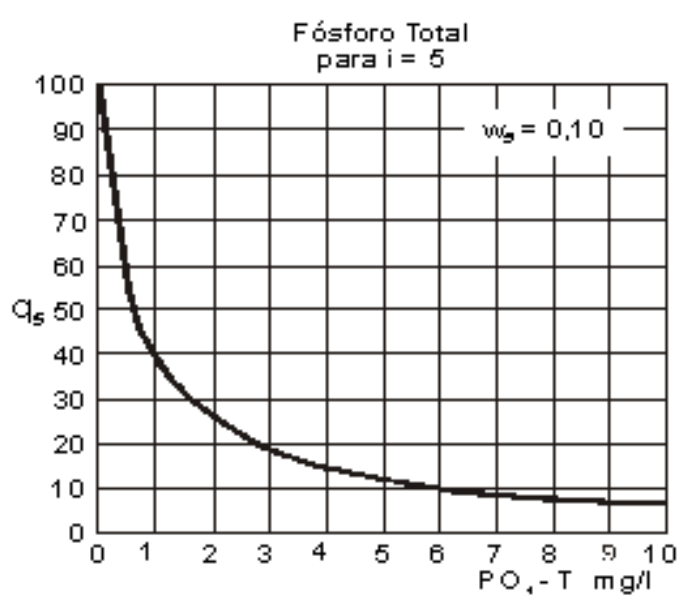

Temperatura

(afastam ento da temperatura de equilíbrio) para $\mathrm{i}=6$

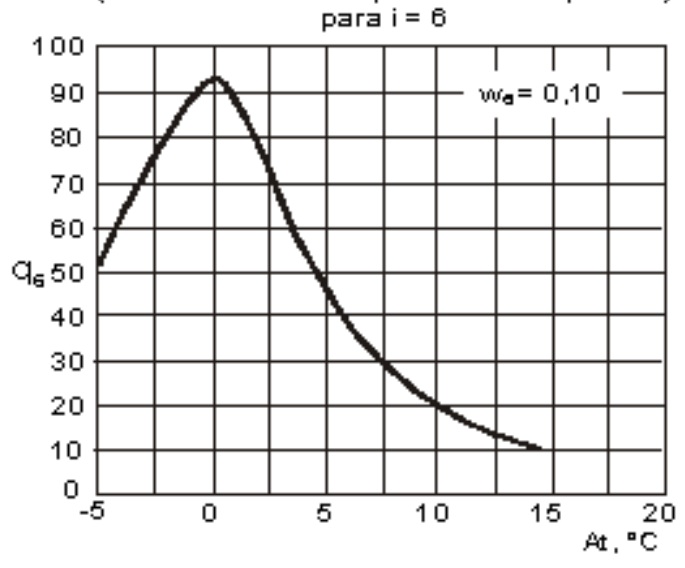

Nota: se Po, $-T>10,0, q=1,0$

Nota: $\approx \Delta t<-5,0$ qaé indefinido se $\Delta \mathrm{t}>15,0 \quad \mathrm{q}_{\mathrm{a}}=9.0$

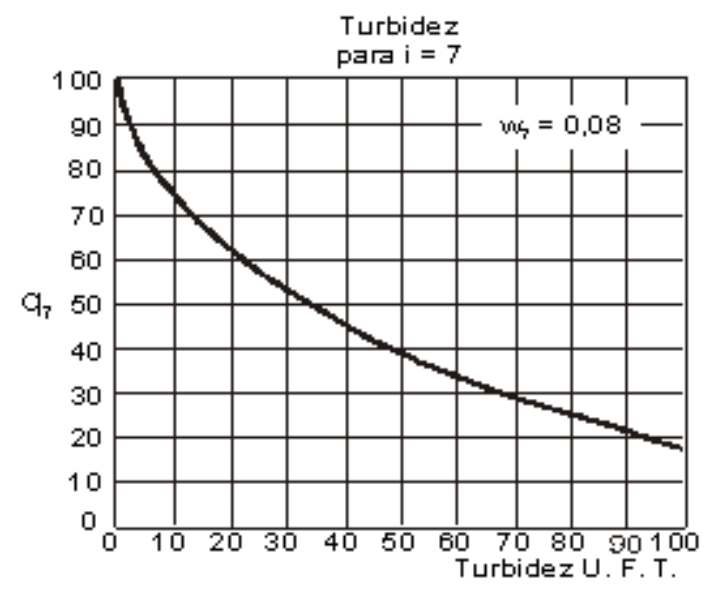

Nota: se turbidez $>100, q_{7}=5,0$
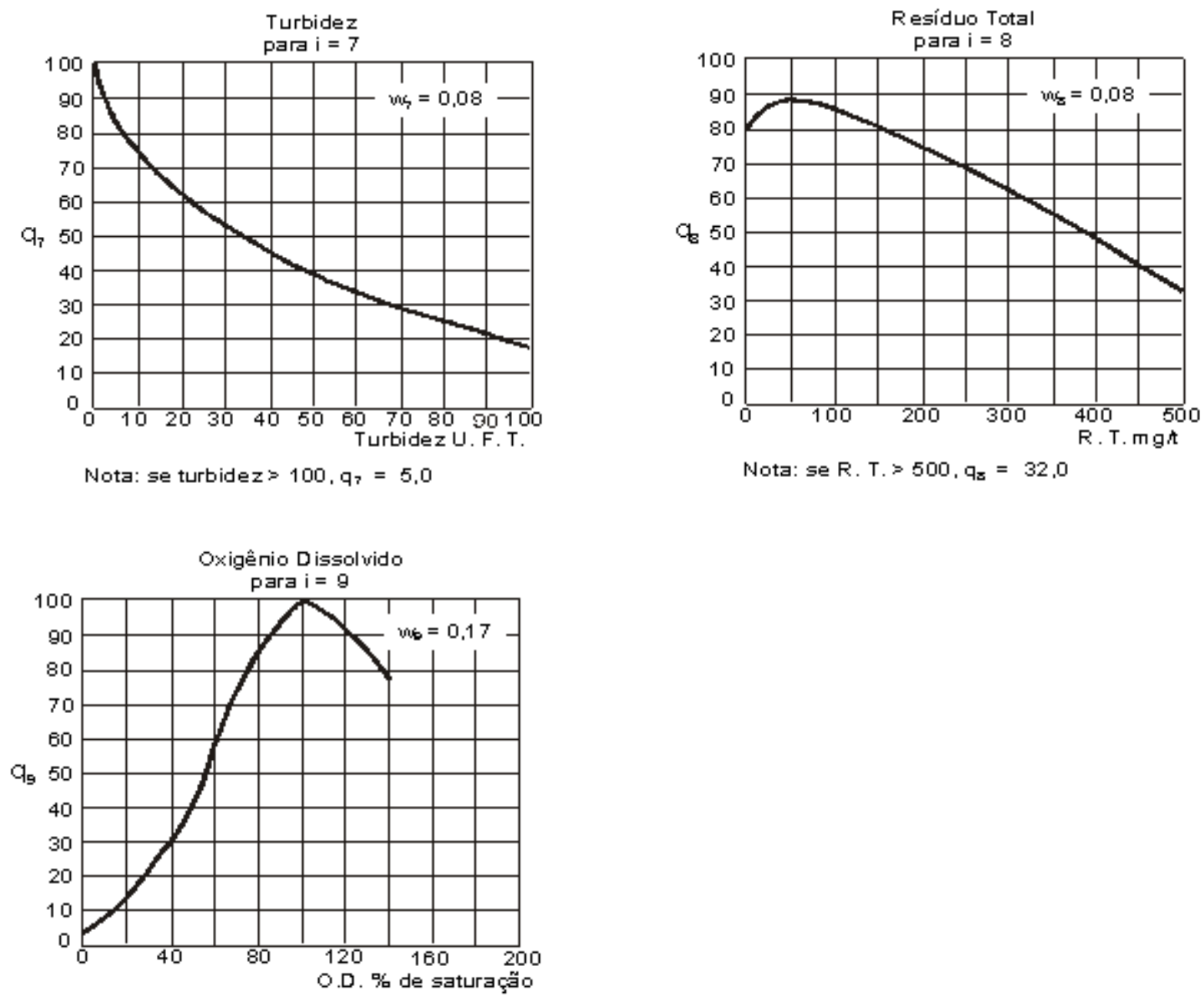

Nota: se OD. \%sat. $>140, q_{0}=47,0$

Figura 5 (CONTINUAÇÃO) - Curvas de variação da qualidade das águas.

Fonte: CETESB (2007). 
Para o cálculo do IQA dispõe-se de duas expressões matemáticas;

- $\quad$ IQA aditivo;

$$
I Q A_{A}=\sum_{i=1}^{9} q i \times W i(\text { Equação } 1)
$$

- IQA multiplicativo;

$$
I Q A_{M}=\prod_{i=1}^{9} q i^{w i}(\text { Equação 2) }
$$

Em que:

- $\quad$ IQA= Índice de Qualidade da Água, (varia de 0 a 100);

- qi = qualidade do i-ésimo parâmetro, (entre 0 e 100); obtido da respectiva "curva de qualidade" em função de sua concentração ou medida.

- $\quad$ wi = peso correspondente ao i-ésimo parâmetro; atribuído por sua importância para a conformação global da qualidade, um número entre 0 e 1 .

No caso de não se dispor do valor de algum dos nove parâmetros, o cálculo do IQA é inviabilizado.

A faixa de classificação varia de zero a cem a qual qualifica a água desde péssima a excelente passando pelas faixas ruim, aceitável e boa.

Tabela 2 - Nível de qualidade da água de acordo com IQA

\begin{tabular}{cc}
\hline \hline NÍVEL DE QUALIDADE & FAIXA \\
\hline \hline Excelente & $90<$ IQA $\leq 100$ \\
Bom & $70<$ IQA $\leq 90$ \\
Aceitável & $50<$ IQA $\leq 70$ \\
Ruim & $25<$ IQA $\leq 50$ \\
Péssima & $00<$ IQA $\leq 25$ \\
\hline \hline
\end{tabular}

Fonte: IGAM, 2003 apud CARVALHO et al, 2004.

Para FERREIRA (2006), a formulação do IQA aditivo, mesmo sendo de fácil compreensão e determinação, não é suficiente para refletir os efeitos que um parâmetro possa causar no resultado final, sendo o IQA multiplicativo mais comumente usado.

Um índice de qualidade das águas pode ser projetado para uma situação específica, inserido no contexto de uma bacia hidrográfica, trazendo consigo a diversidade urbano-industrial presente, a prática de uso e ocupação do solo e o padrão de desenvolvimento tecnológico. $\mathrm{Ou}$ seja, a elaboração de um índice de qualidade das águas pode ser simplificada ao levar em consideração somente as variáveis ambientais críticas que afetam determinado corpo hídrico em um determinado momento. Essa redução do número de variáveis ambientais, graças à escolha daquelas que realmente afetam a qualidade, facilita a elaboração de um índice de qualidade, tornando também sua aplicação mais econômica e desse modo aumentando sua possibilidade de uso em diversas bacias hidrográficas do país (SILVA \& JARDIM, 2006).

A Tabela 4 demonstra a representatividade de cada componente do IQA por intermédios de seus pesos. 
Tabela 3 - Peso dos parâmetros representativos para o cálculo do IQA.

\begin{tabular}{ccc}
\hline \hline PARÂMETRO & UNIDADE & PESO (W) \\
\hline \hline Oxigênio Dissolvido (OD) & \% saturação & 0,17 \\
Coliformes Termotolerantes (CTer) & $\mathrm{NMP} / 100 \mathrm{~mL}$ & 0,15 \\
$\mathrm{pH}$ & - & 0,12 \\
$\mathrm{DBO}_{5}$ & $\mathrm{mg} \mathrm{O}_{2} / \mathrm{L}$ & 0,10 \\
Nitrogênio Total (NT) $_{\text {Fósforo Total (PT) }}^{\mathrm{mg} \mathrm{N} / \mathrm{L}}$ & 0,10 \\
Turbidez (Tur) & $\mathrm{mg} \mathrm{P} / \mathrm{L}$ & 0,10 \\
Sólidos Totais (ST) & $\mathrm{UNT}$ & 0,08 \\
Temperatura (Ta) & $\mathrm{mg} / \mathrm{L}$ & 0,08 \\
\hline \hline
\end{tabular}

Fonte: Adaptado CETESB, 2007.

\section{MATERIAIS E MÉTODOS}

\subsection{LOCALIZAÇÃO}

Segundo o CPRM - Serviço Geológico do Brasil (2005), o município de Mossoró situa-se na mesorregião Oeste Potiguar e na microrregião Mossoró, limitando-se com os municípios de Tibau, Grossos, Areia Branca, Serra do Mel, Açu, Upanema, Governador Dix-Sept Rosado, Baraúna e o Estado do Ceará, abrangendo uma área de $2.100 \mathrm{Km}^{2}$. A sede do município tem uma altitude média de $16 \mathrm{~m}$ e apresenta coordenadas $05^{\circ} 11^{\prime} 16,8^{\prime \prime}$ de latitude sul e $37^{\circ} 20^{\prime} 38,4^{\prime \prime}$ de longitude oeste, distando da capital cerca de $277 \mathrm{~km}$, sendo seu acesso, a partir de Natal, efetuado através da rodovia pavimentada BR-304.

O Rio Mossoró nasce entre o Rio Grande do Norte com a Paraíba, em São Brás, município de Luís Gomes, e faz um percurso de 300 quilômetros aproximadamente, sendo o maior rio do Estado (JORNAL DE FATO, 2005).

As análises realizadas estão centradas na região do rio que corta o município de Mossoró no Estado do Rio Grande do Norte.

\subsection{PONTOS DE COLETA}

Com o auxílio do GPS Garmin eTrex, três pontos de coleta foram devidamente georreferenciados (Tabela 5, Figura 6), sendo suas coordenadas apresentadas a seguir:

Tabela 4 - Coordenadas georreferenciadas dos 3 pontos de coleta

\begin{tabular}{cccc}
\hline \hline PONTOS & BARRAGEM DO GENÉSIO & BARRAGEM CENTRAL & PASSAGEM DE PEDRA \\
\hline \hline utmN- WGS84 & 681464 & 683867 & 690119 \\
utmL - WGS84 & 9422890 & 9425546 & 9429968 \\
Elevação (m) & 14 & 19 & 11 \\
\hline \hline
\end{tabular}




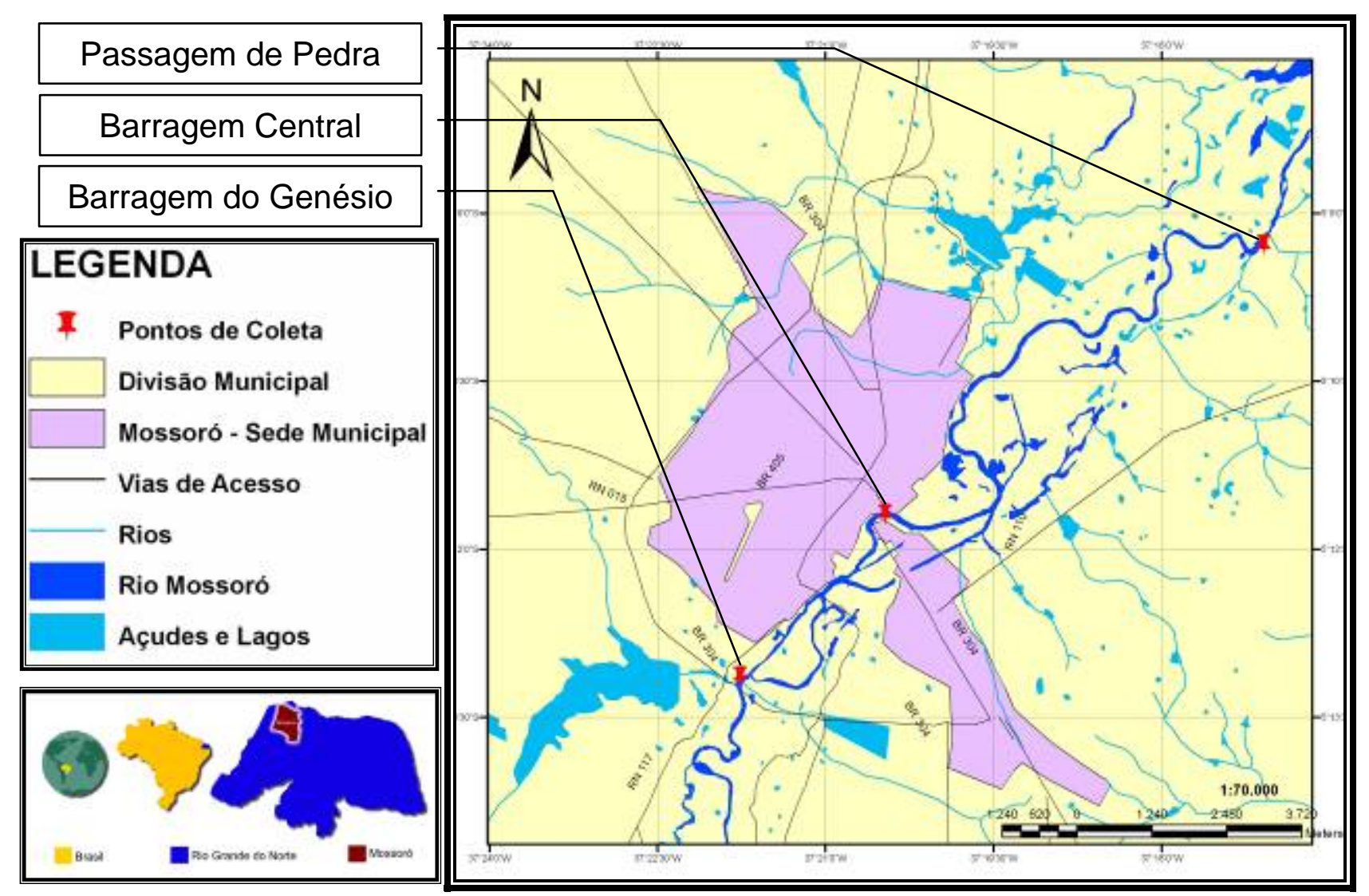

Figura 6 - Esquema representativo de localização dos pontos de coleta.

Esses pontos consistem de uma amostragem em barragens ao longo do Rio Mossoró (Figura 6) que objetiva comparar os parâmetros analisados com a legislação vigente, levando em consideração o perímetro urbano e áreas próximas.

- Barragem do Genésio - BG (Figura 7), situada a montante da cidade localiza-se sob a ponte da BR-304;

- Barragem Central - BC (Figura 8), situada no centro da cidade;

- Passagem de Pedra - PP (Figura 9), situada a jusante da cidade.

Observa-se que o rio corta a Cidade no sentido sudoeste-nordeste, apresentando-se sinuoso nessa região e com vários açudes e lagos nas proximidades de suas margens. Sua várzea apresenta larguras apreciáveis, da ordem de 500 a $1000 \mathrm{~m}$, estreitando-se junto ao Centro, onde existem três pontes que fazem a ligação entre a parte mais antiga da Cidade, na margem esquerda do rio, e o Bairro Alto de São Manuel, que se desenvolveu mais recentemente na margem direita do rio. 


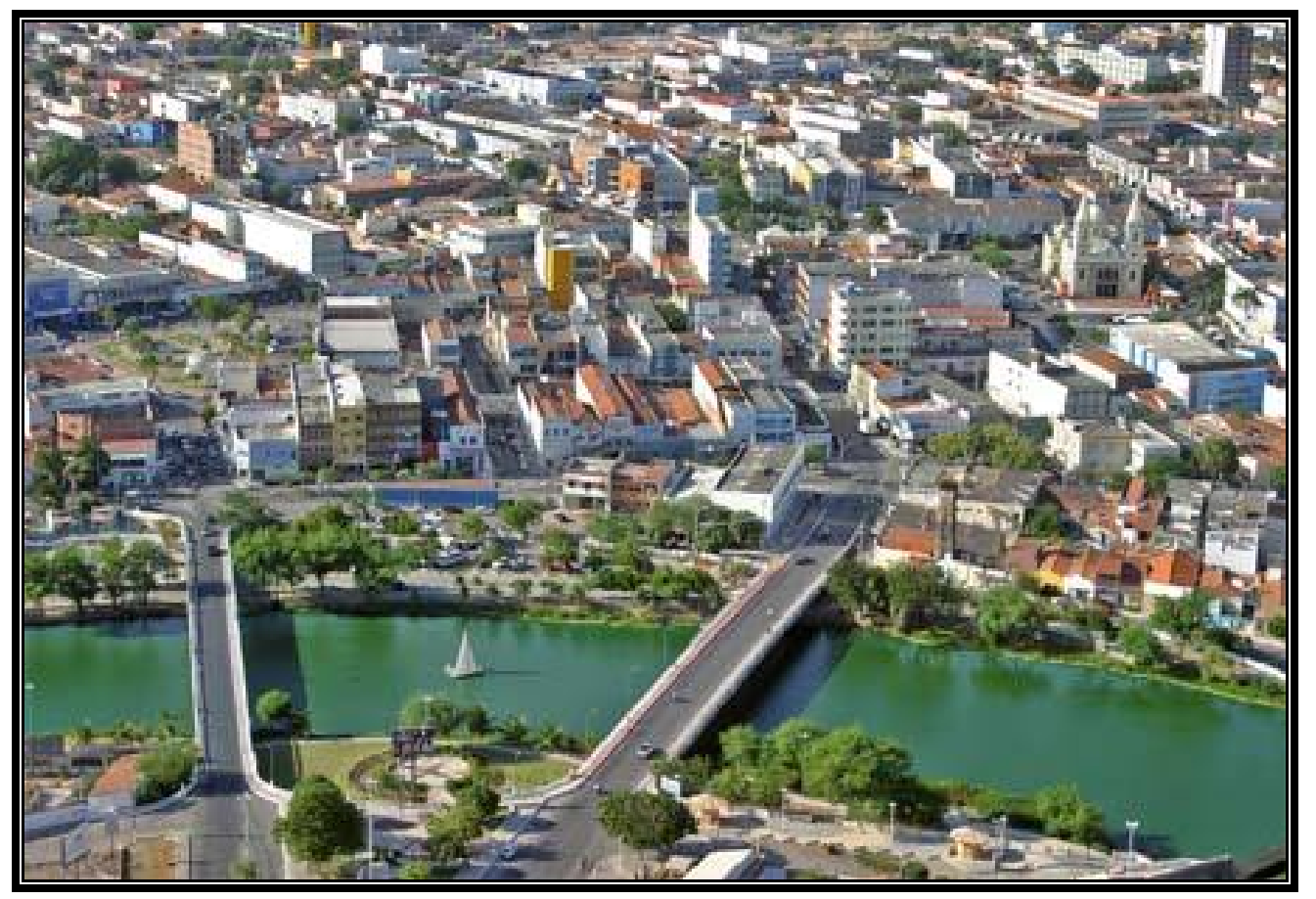

Figura 7 - Vista aérea do centro da cidade, em destaque o Rio Mossoró.

Fonte: http://pt.wikipedia.org/wiki/Imagem:Mossoro_aerea.jpg

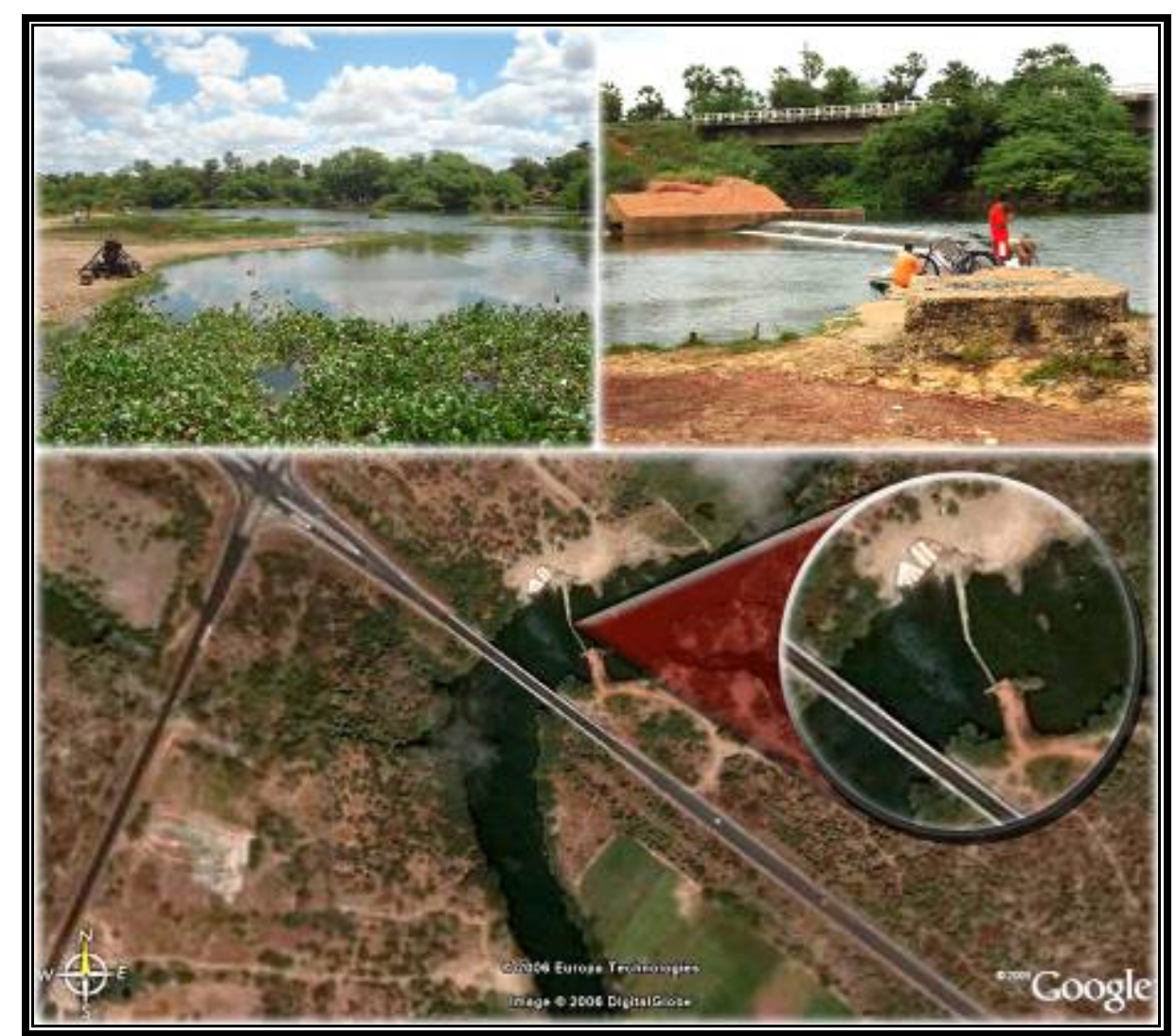

Figura 8 (adaptado Google Earth) - Vista do ponto de coleta da Barragem do Genésio. 


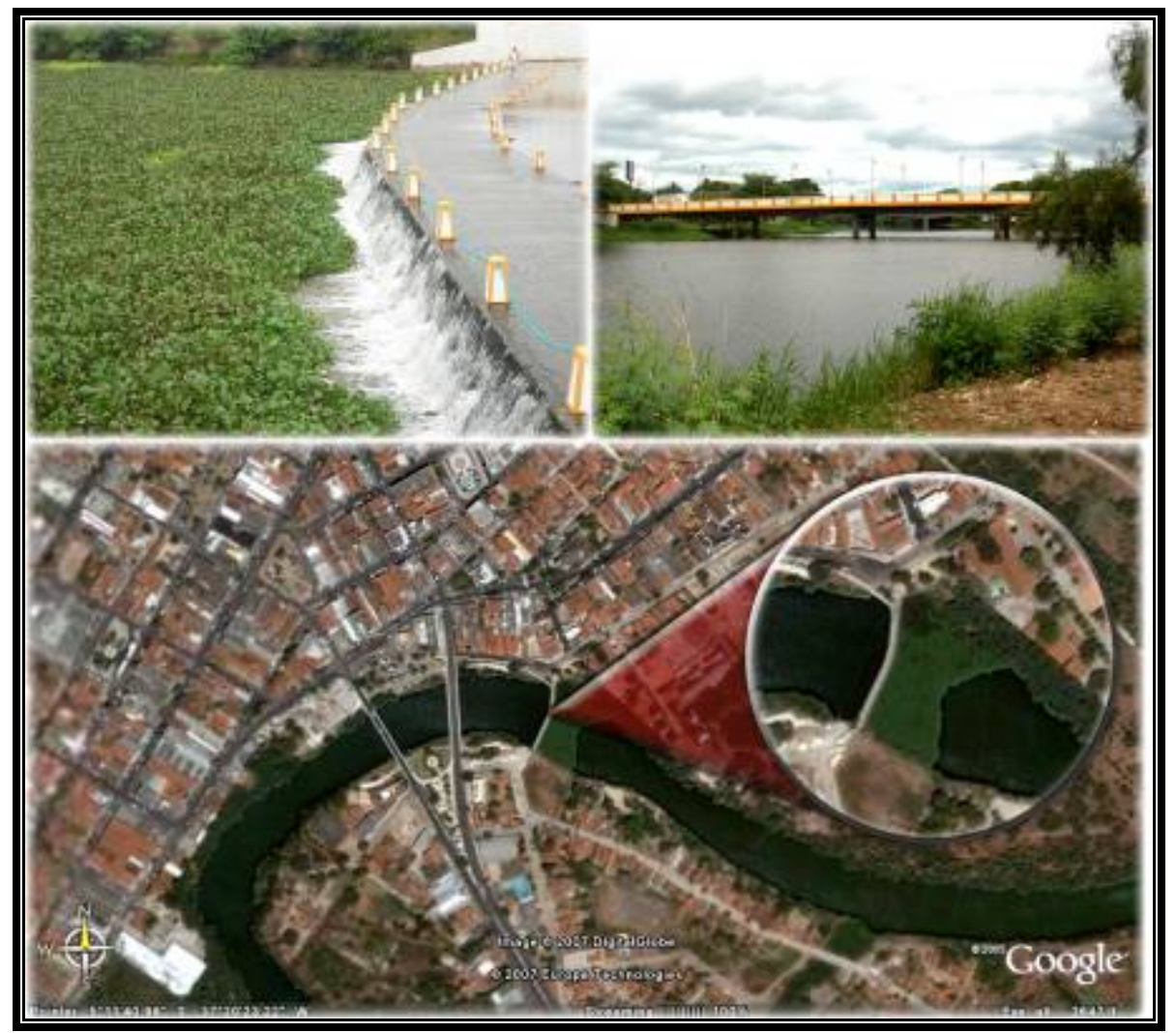

Figura 9 (adaptado Google Earth) - Vista do ponto de coleta da Barragem Central.

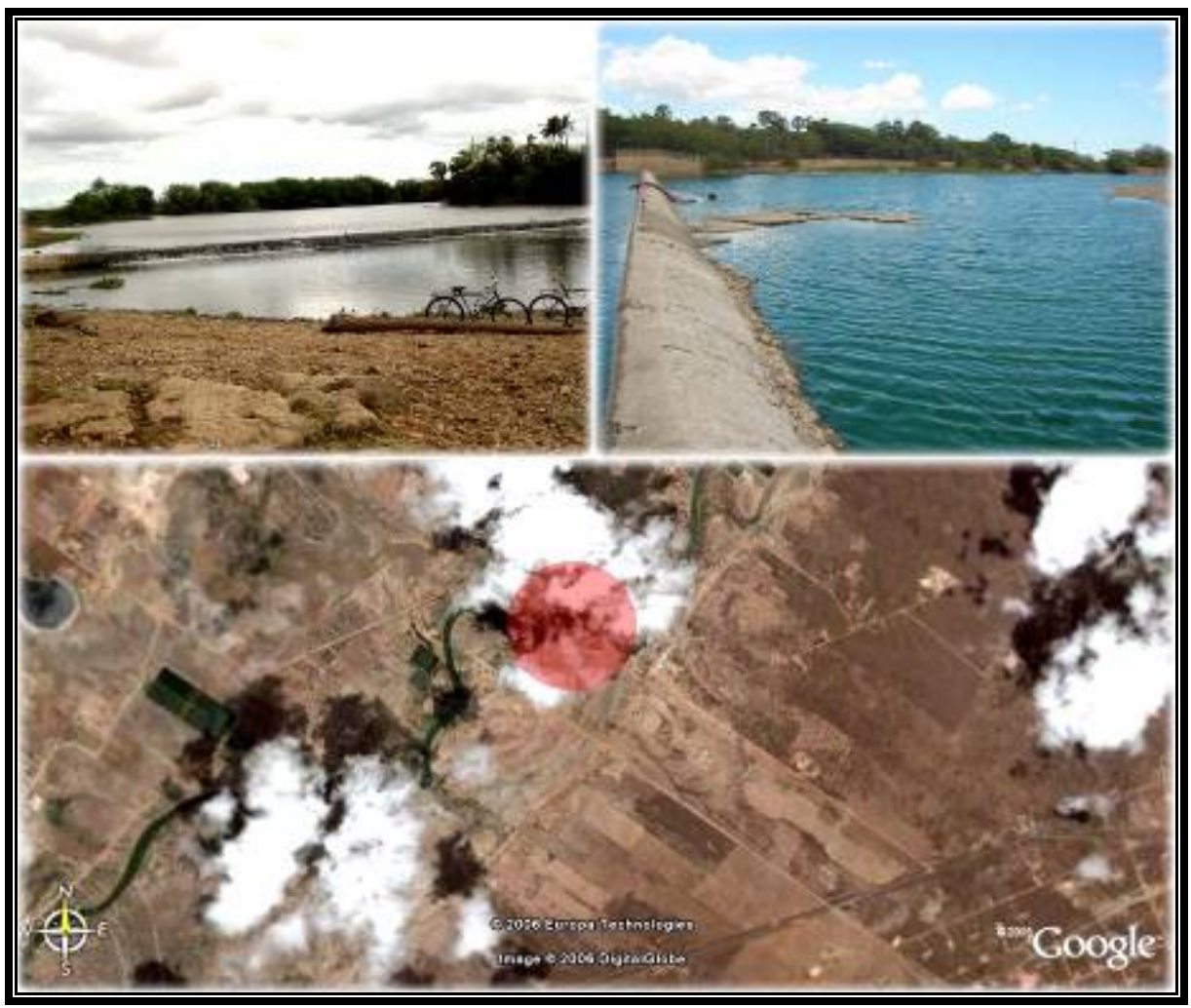

Figura 10 (adaptado Google Earth) - Vista do ponto de coleta da Barragem Passagem de Pedra encoberta por nuvens. 


\subsection{MÉTODOS DE COLETA}

As amostras foram coletadas em triplicata a montante das barragens e analisadas posteriormente no Laboratório de Análises de Águas e Efluentes do Departamento Acadêmico de Recursos Naturais do Centro Federal de Educação Tecnológica do Rio Grande do Norte CEFET/RN.

Para cada tipo de análise, as amostras foram coletadas em frascos apropriados e devidamente preservados, seguindo os padrões descritos em APHA et al. (1995). Relativo aos procedimentos analíticos, todas as análises foram realizadas seguindo os padrões preconizados em APHA et al. (1992).

- Para determinação de metais as amostras foram coletadas em frascos âmbar de 1L e acidificadas para a preservação;

- As amostras para análises microbiológicas foram coletadas em frascos de polipropileno de $250 \mathrm{ml}$ previamente esterilizados. O processo de esterilização foi realizado em autoclave a $121^{\circ} \mathrm{C} / 15 \mathrm{~min}$. Nos frascos foram adicionados previamente $0,3 \mathrm{ml} / 100 \mathrm{ml}$ de solução de EDTA a 15\%, agente quelante, para reduzir a ação tóxica de metais (FERREIRA, 2006). No processo de coleta, tomando todos os cuidados assepsia, removeu-se a tampa do frasco juntamente com o papel coletor, papel alumínio, mergulhando o frasco com a boca para baixo cerca de $30 \mathrm{~cm}$ e enchendo-o até $2 / 3$ do seu volume total. Por fim, acondicionaramse os fracos em caixa térmica com gelo para tornar a temperatura em torno de $10^{\circ} \mathrm{C}$. $\mathrm{O}$ intervalo entre a coleta e a análise laboratorial foi sempre inferior a 6 horas.

- Foram utilizados frascos de DBO para a coleta de amostras para as determinações de oxigênio dissolvido, com fixação da amostra no próprio ponto de coleta utilizando soluções de sulfato manganoso e iodeto de azida.

- Para as determinações físico-químicas as amostras foram coletadas em frascos de plásticos de $1 \mathrm{~L}$, previamente lavadas com solução ácido clorídrico (10\%), enxaguadas com água e posteriormente com água destilada.

\subsection{TRATAMENTO ESTATÍSTICO DOS DADOS}

O período de monitoramento em questão, abril/2005 a julho/2006, resulta na análise de 5 coletas in loco. Além dessas, uma sexta coleta, a mais recente (10 de Janeiro de 2007), foi a base de cálculo para Índice de Qualidade de Águas - IQA.

As coletas foram realizadas em triplicatas o que possibilita um resultado preciso dos parâmetros em questão e promove uma maior confiabilidade dos resultados. Essas coletas se deram a montante das barragens gerando por ponto três baterias de dados referentes aos parâmetros analisados (Figura 10). O tratamento dos dados deu-se da seguinte forma: por cada dia de coleta fez-se inicialmente a média aritmética simples da triplicada (média parcial). Em seguida, aferiu-se a média geral, o mínimo e o máximo proveniente dos cálculos de todas as coletas.

O tratamento dos dados levantados foi realizado com o auxílio do software STATISTICA 6.0 da StatSoft, para assim comparar os resultados com a resolução CONAMA 357, de 17 de março de 2005. 


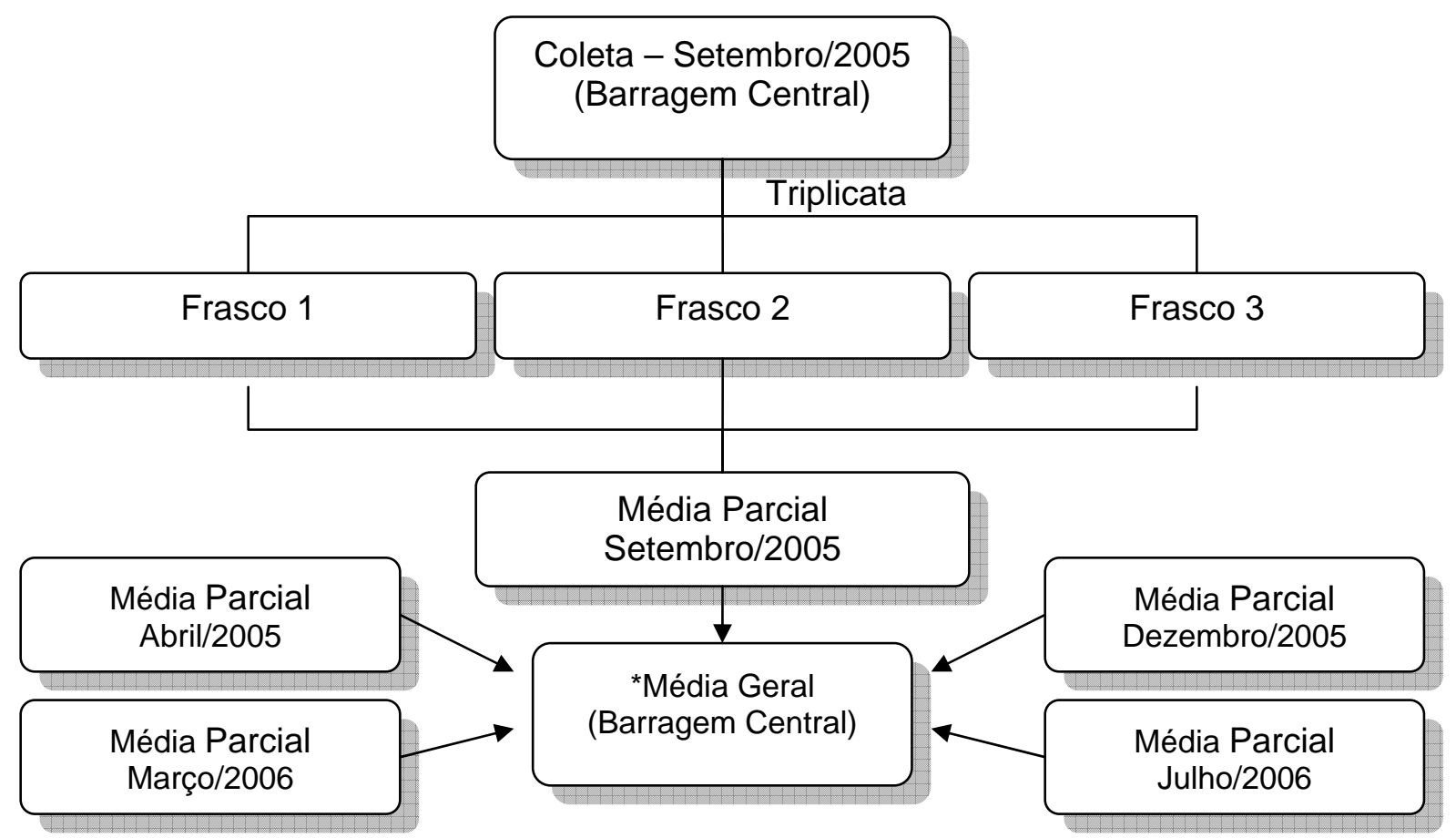

* Ao longo do texto, o termo média geral será abreviado em “média”.

Figura 11 - Esquema de exemplificação da metodologia de tratamento dos dados.

\section{RESULTADOS E DISCUSSÕES}

A temperatura média anual na Cidade de Mossoró (Figura 11), no período de 1971 a 1990 foi de $27,5^{\circ} \mathrm{C}$, com a menor média compensada mensal observada no mês de julho $\left(26,5^{\circ} \mathrm{C}\right)$ e a maior, no mês de dezembro $\left(28,4^{\circ} \mathrm{C}\right)$. As amplitudes térmicas são ligeiramente maiores nos meses secos e menores nos chuvosos. A temperatura máxima absoluta, no mesmo período foi de $38^{\circ} \mathrm{C}$ e a mínima absoluta de $16,2^{\circ} \mathrm{C}$.

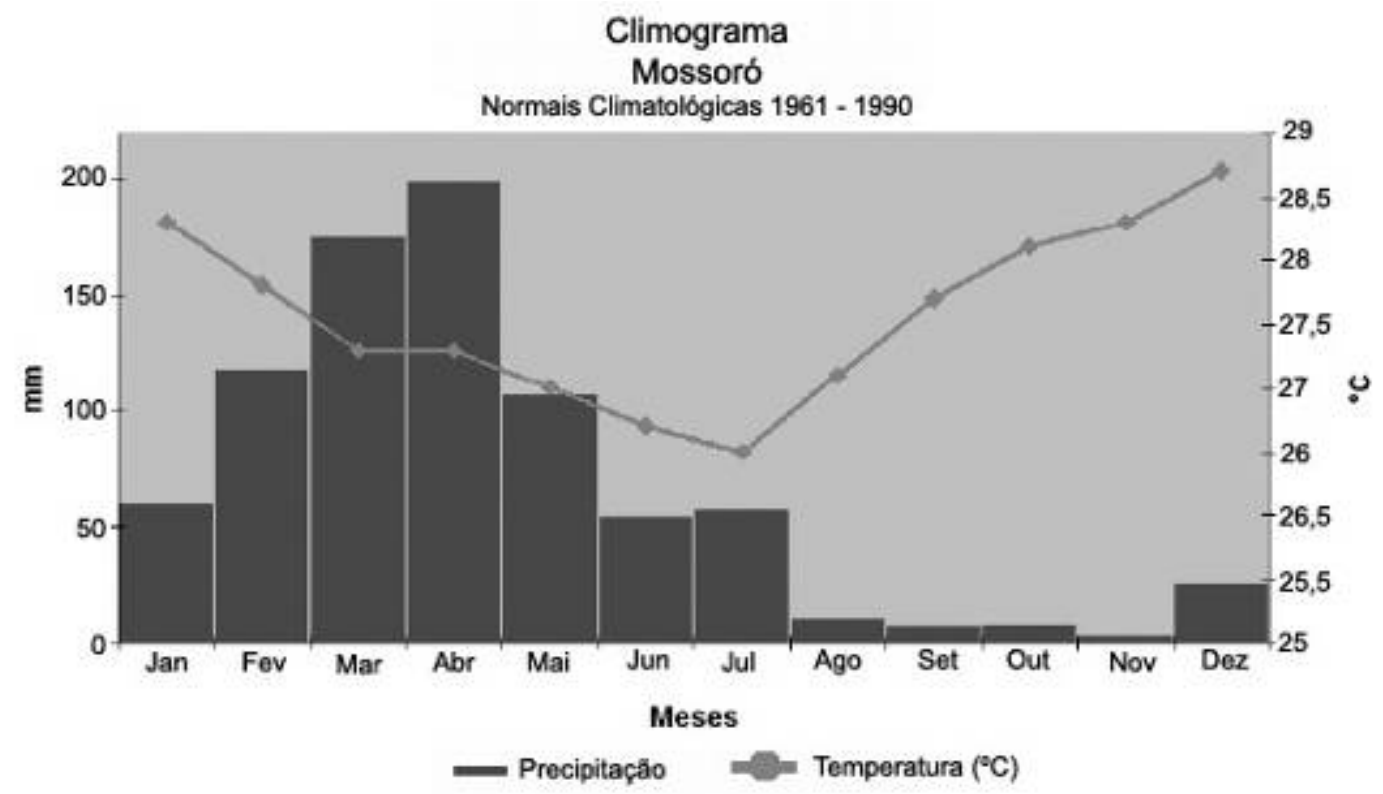

Figura 12 - Climograma de Mossoró.

Fonte: INMET, 1990 apud BAPTISTA et al, 2005. 


\subsection{PARÂMETROS MICROBIOLÓGICOS (COLIFORMES TOTAIS E TERMOTOLERANTES).}

A partir do tratamento dos dados, observou-se grande variação entre os valores mínimos e máximos de coliformes termotolerantes em todas as barragens (Tabela 6). Uma possível hipótese levantada para essa notável diferença diz respeito à sazonalidade local, visto que os picos de concentração ocorreram no período em que o fluxo natural do rio (ambiente lótico) estava baixo, assemelhando-se a um ambiente lêntico, devido à baixa vazão. A citar exemplo, na coleta realizada em dezembro de 2005 , aferiu-se que as águas estavam estagnadas e abaixo cerca $30 \mathrm{~cm}$ da crista das barragens.

Tabela 5 - Resultados médios dos parâmetros microbiológicos

\begin{tabular}{ccc}
\hline \hline ORIGEM & COLIFORMES TERMOTOLERANTES & COLIFORMES TOTAIS \\
\hline \hline BG & 1316 & 88746 \\
BC & 46867 & 224792 \\
PP & 6851 & 93321 \\
\hline \hline
\end{tabular}

Para uso de recreação de contato primário devem ser obedecidos os padrões de qualidade de balneabilidade, previstos na Resolução CONAMA n ${ }^{\circ}$ 274, de 29 de novembro de 2000. Para os demais usos, orienta-se pela Resolução 357/05 em que não se deve exceder um limite de 200 coliformes termotolerantes para Classe 1 e um limite de 1000 coliformes termotolerantes para Classe 2. Para uso de contato secundário não deverá exceder um limite de 2500 coliformes termotolerantes, Classe 3.

Falando-se agora das especificidades observadas em cada ponto de coleta, iniciar-se-á os comentários seguindo da região a montante da cidade até o ponto a jusante.

A Barragem do Genésio é o ponto cuja concentração de coliformes foi menor dentre as demais. Em termos de coliformes totais (Figura 12), é a barragem em que houve maior discrepância entre os valores de concentração máxima e mínima, valendo salientar que não há valores limites para coliformes totais definidos segundo a Resolução CONAMA 357/05. Referente aos coliformes termotolerantes (Figura 13), a barragem apresenta períodos em que se encaixa em rio Classe 1, Classe 2 e Classe 3, embora a média da amostras o classifica em Classe 3.

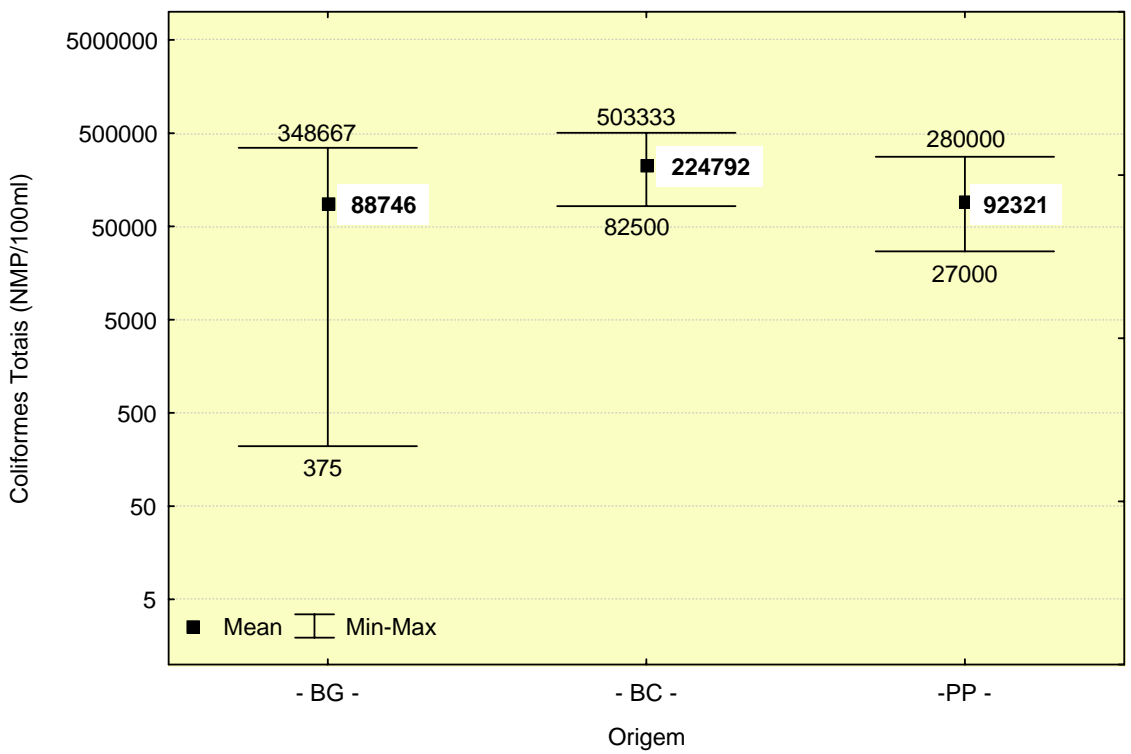

Figura 13 - Gráfico da variação da concentração de coliformes totais. 
A Barragem Central possui uma média aproximada 40\% maior de concentração de coliformes totais que a Barragem Genésio e Passagem de Pedra. Nesse ponto, as concentrações de coliformes termotolerantes sempre estiveram bem acima da preconização do limite máximo para Classe 3 da legislação vigente. Podendo-se inferir que, nessa região, o rio vem recebendo lançamento de efluentes sem tratamento. Durante a coleta in loco, sente-se o odor característico de esgoto doméstico.

A barragem Passagem de Pedra, localizada a jusante da cidade, apresenta concentração média de coliformes totais semelhante à Barragem do Genésio, embora a concentração mínima seja bastante diferente.

Em termos de coliformes termotolerantes (Figura 13), Passagem de Pedra oscila entre as três Classes preconizadas, tendo na média valores de concentração superiores aos limites preconizados para Classe 3.

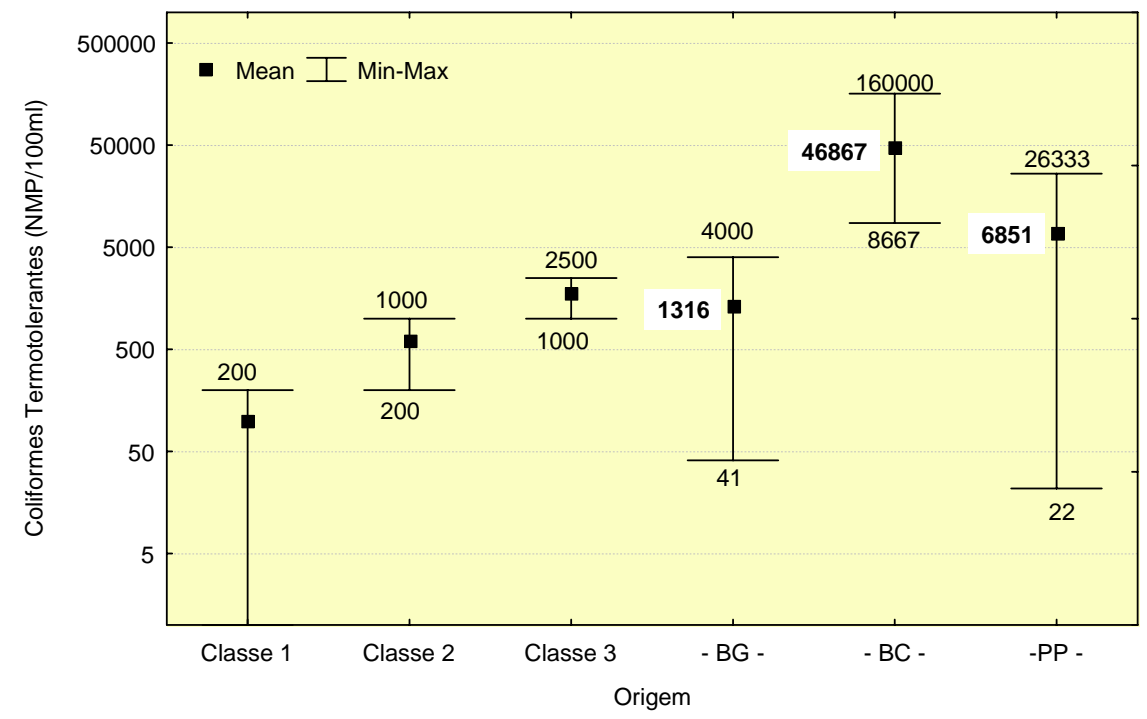

Figura 14 - Gráfico da variação da concentração de coliformes termotolerantes e comparação com a classificação preconizada pela Resolução CONAMA 357/05.

\subsection{PARÂMETROS FÍSICOS (TEMPERATURA, COR E TURBIDEZ).}

A temperatura nos três pontos esteve na faixa de 28 a $29,1^{\circ} \mathrm{C}$, comuns na região. Esse parâmetro é utilizado na caracterização de corpos d'água e caracterização de águas residuárias, pois sua mudança influencia na solubilidade dos gases, na taxa de reações químicas e biológicas em comparação com o normal e na transferência de gases, podendo gerar mau cheiro, no caso de liberação de sulfeto de hidrogênio.

A cor, proveniente dos sólidos dissolvidos, provém da decomposição da matéria orgânica, do ferro e do manganês. Diretamente, a cor não apresenta riscos à saúde, porém num processo de tratamento de água a matéria orgânica dissolvida pode-se combinar com o cloro e formar compostos cancerígenos, como os trialometanos (triclorometano, bromodiclorometano, dibromoclorometano e tribromometano).

Com relação a esse parâmetro (Tabela 7, Figura 14), exceto a Barragem do Genésio enquadrado em Classe 1, todos os outros pontos possuem média que superam os limites estabelecidos para as Classes 2 e $3(\mathrm{COR}<75 \mathrm{UH})$. A título de informação, esse trabalho não 
entrou no mérito da discussão no que refere a igualdade de concentração preconizado para Classe 2 e 3 . Essa classificação dependerá do conjunto de parâmetros apresentados pela resolução que, em sua totalidade, não estão contemplados por esse trabalho.

Tabela 6 - Resultados médios dos parâmetros físicos.

\begin{tabular}{ccc}
\hline \hline ORIGEM & COR (mg/L Pt-Co/L) & TURBIDEZ (UNT) \\
\hline \hline BG & 34,33 & 6,13 \\
BC & 151,96 & 15,33 \\
PP & 190,63 & 37,79 \\
\hline \hline
\end{tabular}

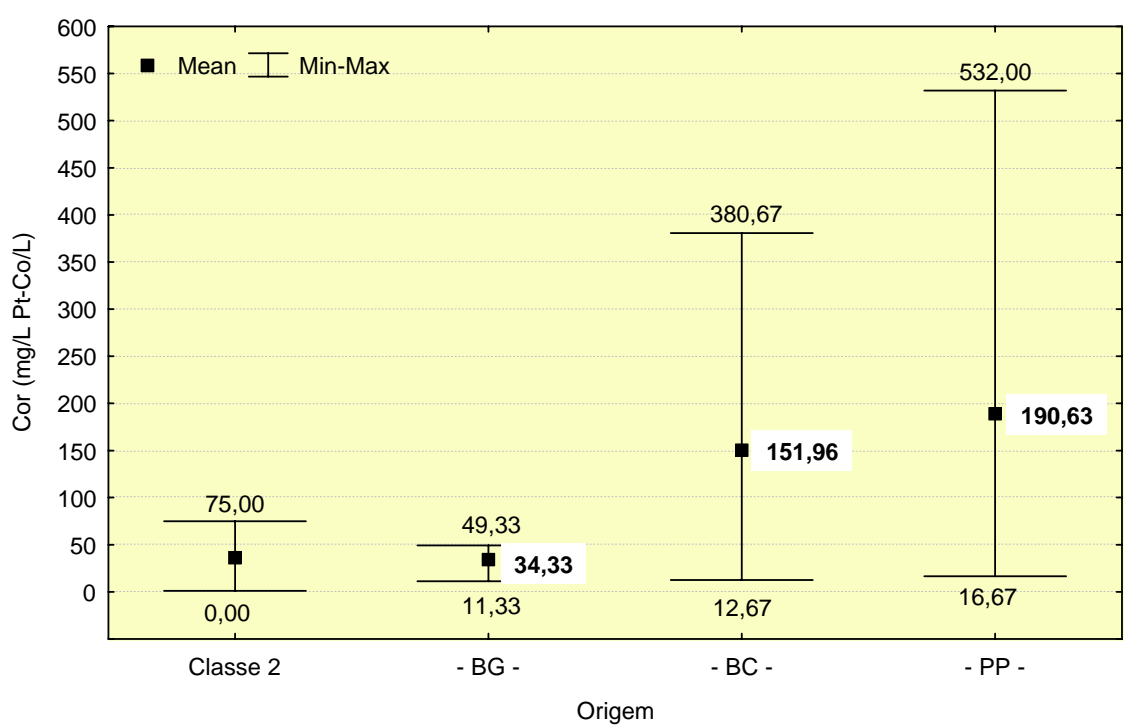

Figura 15 - Gráfico da variação da cor e comparação com a classificação preconizada pela Resolução CONAMA 357/05.

A turbidez mede o grau de dificuldade em que um feixe luminoso é submetido ao atravessar uma amostra de água com presença de sólidos em suspensão (areia, silte, argila, detritos orgânicos, algas e bactérias). Quando em alta concentração, esses sólidos reduzem a fotossíntese das algas, influenciam nas comunidades biológicas aquáticas e afetam a utilização do recurso para uso doméstico, industrial e recreacional.

Nas análises, a turbidez (Figura 15) em Passagem de Pedra apresenta valores acima da preconização para Classe 1 e 2, no entanto a média do período, assim como na BG e $\mathrm{BC}$, estão abaixo do limite permitido para Classe 1 (TURBIDEZ < 40 UNT).

\subsection{PARÂMETROS QUÍMICOS (PH, OXIGÊNIO DISSOLVIDO, DEMANDA QUÍMICA DE OXIGÊNIO E NITRATO E METAIS PESADOS).}

Os valores de $\mathrm{pH}$ (Tabela 8 , Figura 16) em todas as barragens variaram na faixa alcalina $(7,37$ a 8,79). Os valores se encaixaram na faixa estabelecida para águas doce Classe 1 ( $\mathrm{pH}$ entre $6 \mathrm{e}$ 9). 


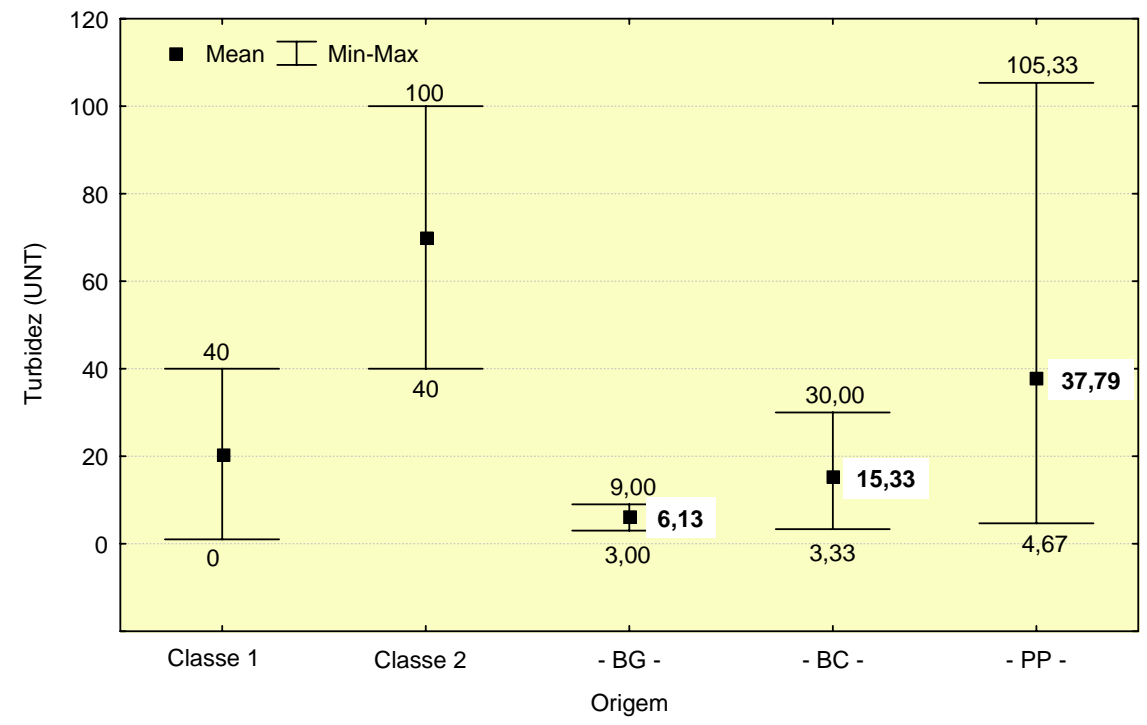

Figura 16 - Gráfico da variação da turbidez e comparação com a classificação preconizada pela Resolução CONAMA 357/05.

Tabela 7 - Resultados médios dos parâmetros químicos

\begin{tabular}{|c|c|c|c|c|}
\hline ORIGEM & pH & $\begin{array}{c}\text { OXIGÊNIO DISSOLVIDO } \\
\left(\mathrm{mg} / \mathrm{L} \mathrm{O}_{2}\right)\end{array}$ & $\begin{array}{l}\text { DEMANDA QUÍMICA DE OXIGÊNIO } \\
(\mathrm{mg} / \mathrm{L})\end{array}$ & $\begin{array}{l}\text { NITRATO } \\
(\mathrm{mg} / \mathrm{L} \mathrm{N})\end{array}$ \\
\hline $\mathrm{BG}$ & 7,98 & 8,308 & 23,97 & 0,74 \\
\hline $\mathrm{BC}$ & 7,96 & 6,664 & 40,58 & 2,85 \\
\hline PP & 8,23 & 9,334 & 44,58 & 1,02 \\
\hline
\end{tabular}

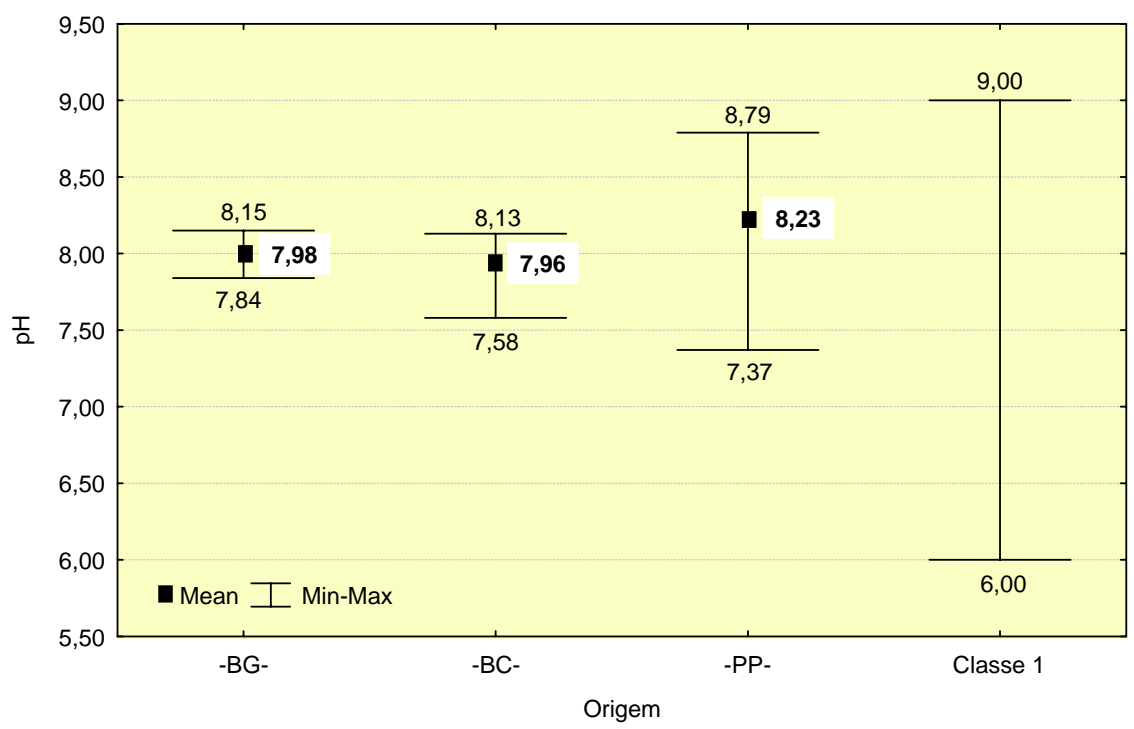

Figura 17 - Gráfico da variação do pH e comparação com a classificação preconizada pela Resolução CONAMA 357/05.

As águas poluídas apresentam baixa concentração de oxigênio dissolvido, devido ao alto consumo proveniente da decomposição de compostos orgânicos, enquanto que as águas limpas apresentam concentrações de oxigênio dissolvido elevadas, chegando até a um pouco abaixo da concentração de saturação 9,2 mg/L O $\mathrm{O}_{2}$ (SPERLING, 1996). Já uma água 
eutrofizada pode apresentar concentrações de oxigênio bem superiores a $10 \mathrm{mg} / \mathrm{L}$, mesmo em temperaturas superiores a $20^{\circ} \mathrm{C}$, caracterizando uma situação de supersaturação.

Na Figura 17, as Barragens do Genésio e Passagem de Pedra apresentaram valores de máximo para oxigênio dissolvido acima da saturação. Encaixando-se na condição de eutrofização, que é evidenciada pela coloração esverdeada na água indicando grande quantidade de algas. É provável que em épocas de menor vazão do rio (semelhança com ambiente lêntico), devido ao aumento do tempo de permanência da água na barragem o processo seja acentuado causando proliferação de macrófitas aquáticas (Figura 18) e a liberação de maus odores durante a decomposição da matéria morta.

A média de OD caracteriza os três pontos na Classe 1, embora tenha tido momentos no ano em que os níveis de oxigênio estavam na faixa de classificação 2 e 3.

Observa-se na Figura 18 que em 12/07/2006 ainda era possível observar a superfície da água livre de macrófitas. Aspecto que mudou em aproximadamente seis meses (10/01/2007) em que estavam cobertos.

Na Figura 19 apresenta as concentrações de nitrato nos pontos amostrados. Todos os pontos de água doce apresentaram concentrações inferiores a 10mg/L estando dentro do limite da Classe 1.

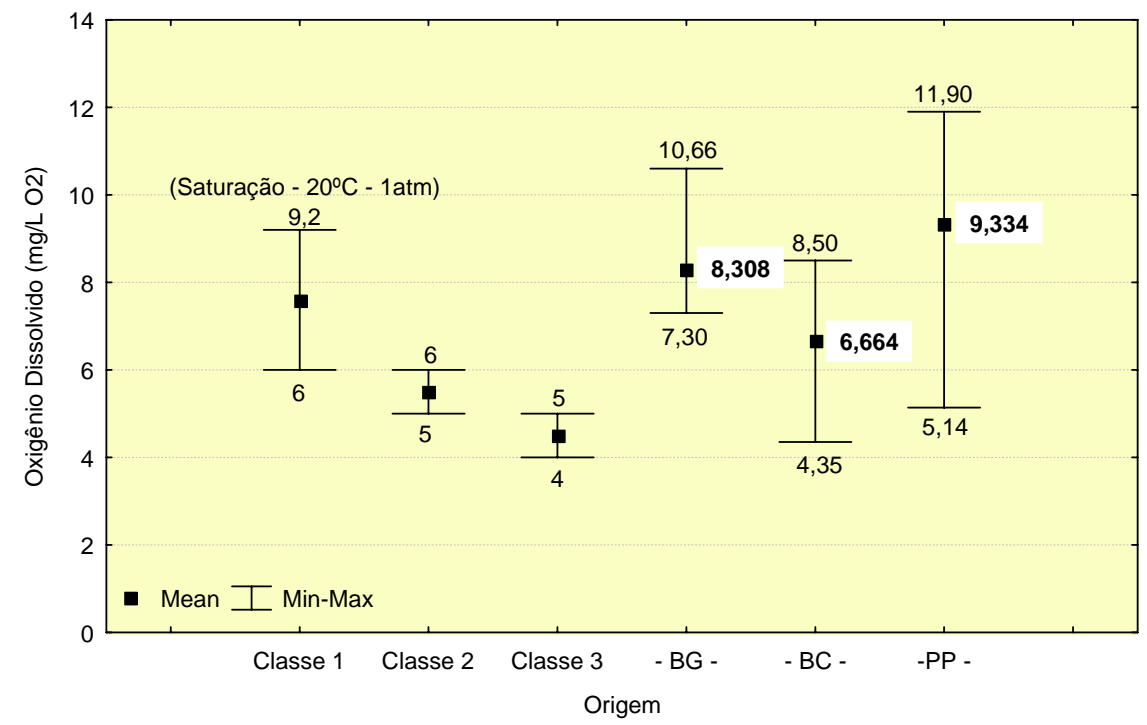

Figura 18 - Gráfico da variação da concentração de oxigênio dissolvido e comparação com a classificação preconizada pela Resolução CONAMA 357/05. 


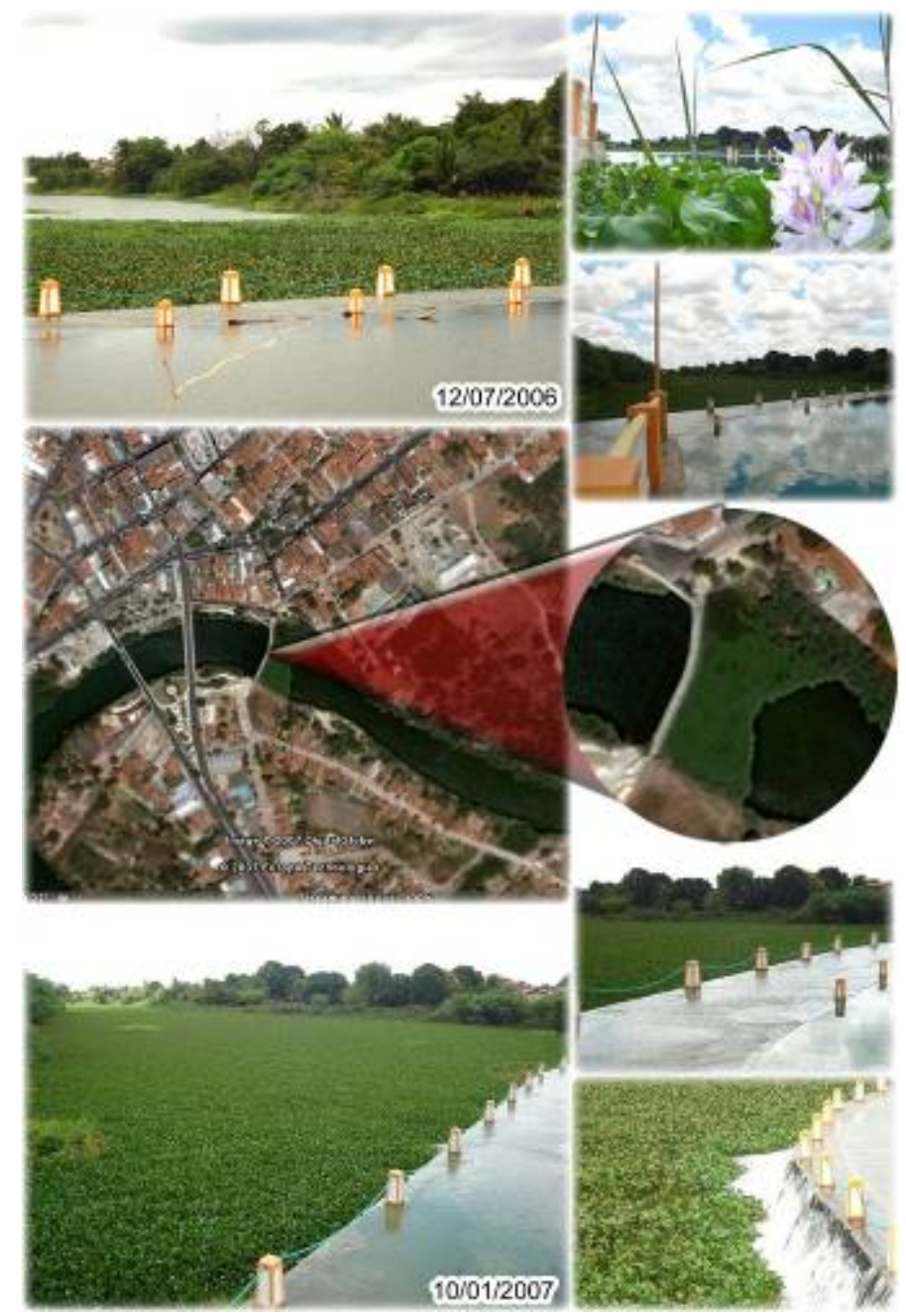

Figura 19 - Proliferação de macrófitas a jusante da Barragem Central simbolizando o processo de eutrofização.

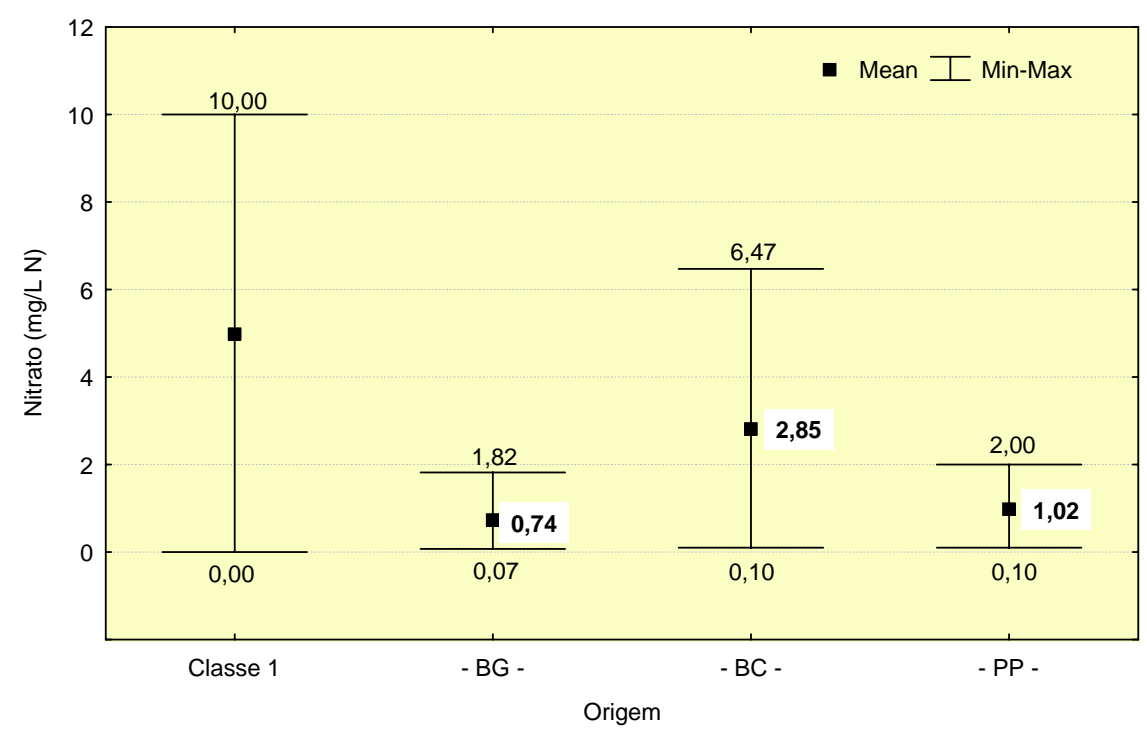

Figura 20 - Gráfico da variação da concentração de nitrato e comparação com a classificação preconizada pela Resolução CONAMA 357/05. 
Conforme verificado através da Tabela 9, Figuras 20, 21 e 22, as concentrações médias dos metais cobre, zinco e cromo, assim como mercúrio e cádmio, que não foram detectados, atendem ao preconizado para águas doces Classe $1,0,009 \mathrm{mg} / \mathrm{L} \mathrm{Cu}, 0,18 \mathrm{mg} / \mathrm{L} \mathrm{Zn,} \mathrm{0,05mg} \mathrm{/L}$ $\mathrm{Cr}$, respectivamente. No entanto, para o cobre, houve momentos em que sua concentração superava $(0,0277 \mathrm{mg} / \mathrm{L} \mathrm{Cu})$ o limite para Classe $3(\mathrm{Cu}<0,013 \mathrm{mg} / \mathrm{L})$. Com relação ao chumbo (Figura 23), todas as médias estão acima do limite permitido para Classe 3 levantando a hipótese de uma característica local da região.

Tabela 8 - Resultados médios dos metais pesados.

\begin{tabular}{ccccccc}
\hline \hline \multirow{2}{*}{ ORIGEM } & $\begin{array}{c}\text { MERCÚRIO } \\
(\mathbf{m g} / \mathbf{L} \text { Hg) }\end{array}$ & $\begin{array}{c}\text { CÁDMIO } \\
(\mathbf{m g} / \mathbf{L} \text { Cd) }\end{array}$ & $\begin{array}{c}\text { CHUMBO } \\
(\mathbf{m g} / \mathbf{L} \text { Pb) }\end{array}$ & $\begin{array}{c}\text { CROMO } \\
(\mathbf{m g} / \mathbf{L} \text { Cr })\end{array}$ & $\begin{array}{c}\text { COBRE } \\
(\mathbf{m g} / \mathbf{L} \mathbf{C u})\end{array}$ & $\begin{array}{c}\text { ZINCO } \\
(\mathbf{m g} / \mathbf{L} \text { Zn })\end{array}$ \\
\hline \hline BG & ND & ND & 0,0407 & 0,0120 & 0,0088 & 0,0370 \\
BC & ND & ND & 0,0462 & 0,0072 & 0,0078 & 0,0189 \\
PP & ND & ND & 0,0562 & 0,0023 & 0,0090 & 0,0497 \\
\hline \hline
\end{tabular}

* ND - Não detectável.

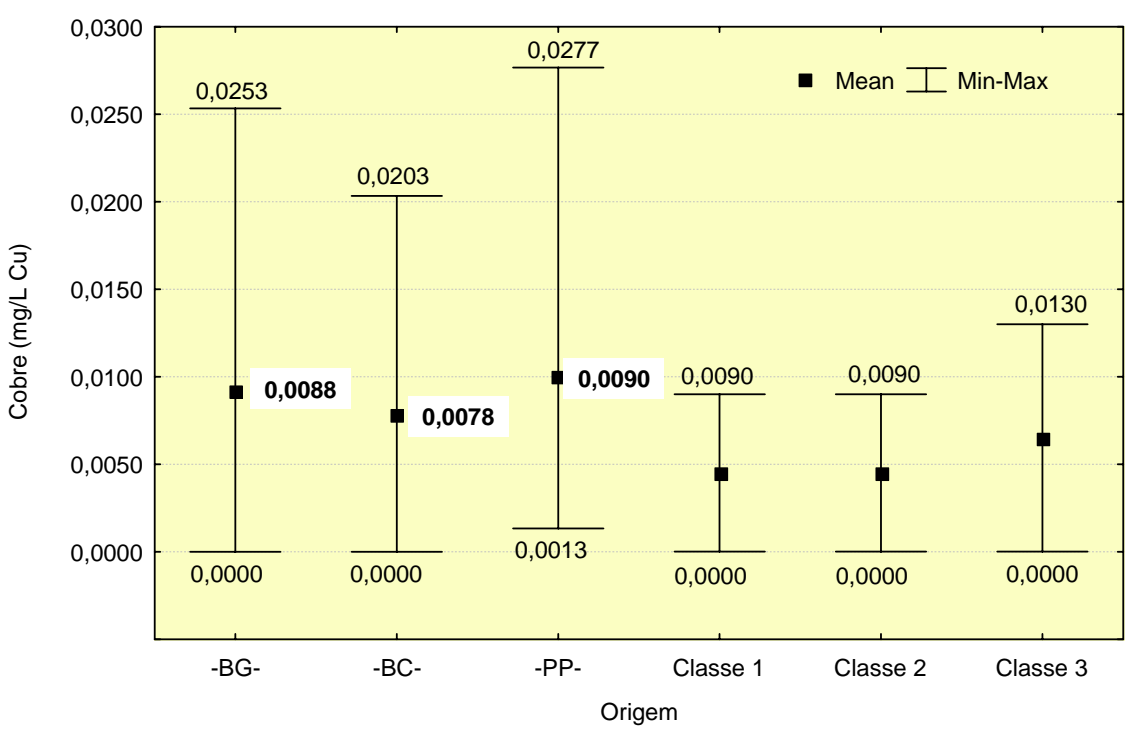

Figura 21 - Gráfico da variação da concentração de cobre e comparação com a classificação preconizada pela Resolução CONAMA 357/05.

\section{4 ÍNDICE DE QUALIDADE ÁGUA - IQA}

Para a identificação e padronização da qualidade da água, utilizou-se o Índice de Qualidade de Água (IQA). Este constitui uma ferramenta prática, de comunicação eficiente, obtida por meio da indexação das informações de diversos parâmetros ou variáveis analisadas.

O IQA calculado segundo os métodos aditivos e multiplicativos mostraram que (Figura 24):

- O nível de qualidade da Barragem do Genésio varia de bom (método aditivo) a aceitável (método multiplicativo).

- O nível de qualidade da Barragem Central varia de aceitável (método aditivo) a ruim (método multiplicativo).

- O nível de qualidade da Barragem Passagem de Pedra varia de aceitável (método aditivo) a ruim (método multiplicativo). 
Independentemente do método do IQA, observou-se que a qualidade da água está diminuindo do ponto a montante da cidade (Barragem do Genésio) no sentido a jusante da cidade (Barragem Passagem de Pedra). Apesar de a Barragem Central apresentar-se similar a Barragem Passagem de Pedra.

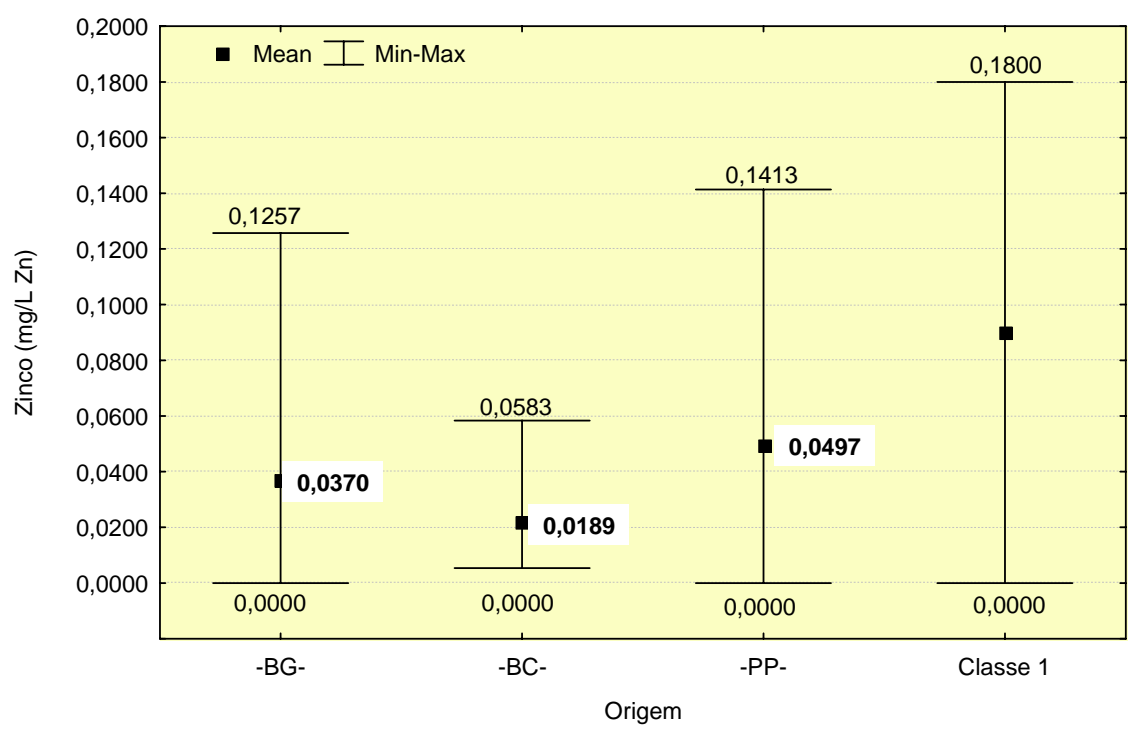

Figura 22 - Gráfico da variação da concentração de zinco e comparação com a classificação preconizada pela Resolução CONAMA 357/05.

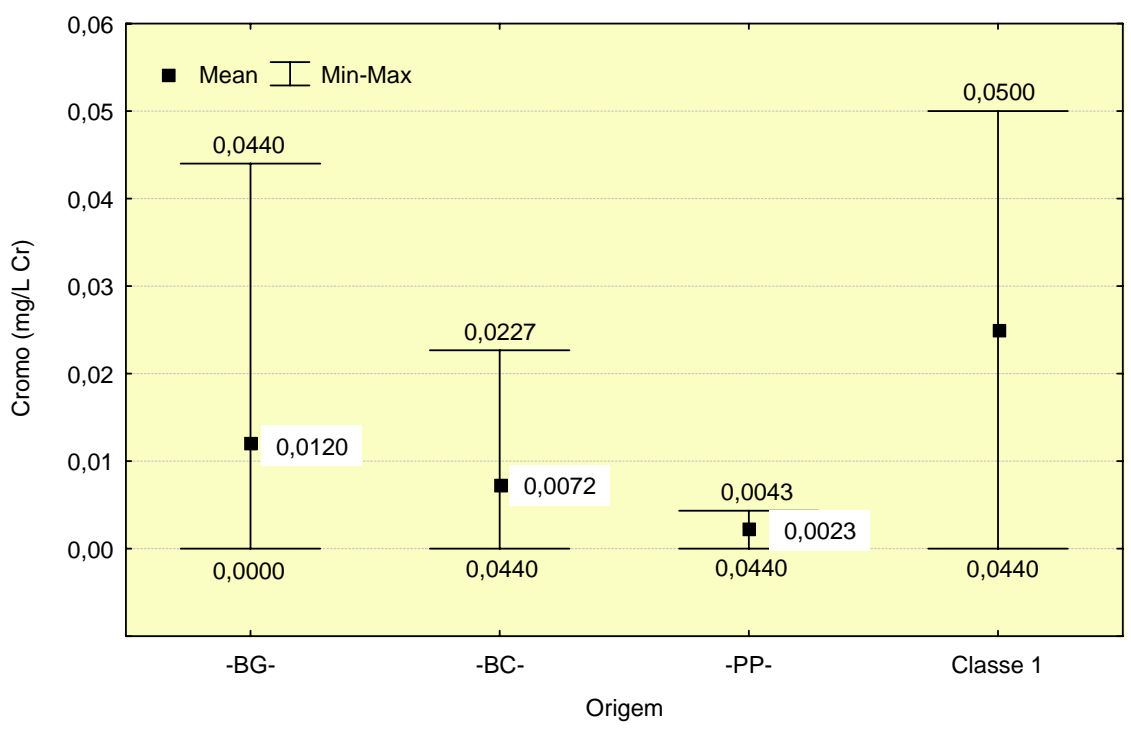

Figura 23 - Gráfico da variação da concentração de cromo e comparação com a classificação preconizada pela Resolução CONAMA 357/05. 


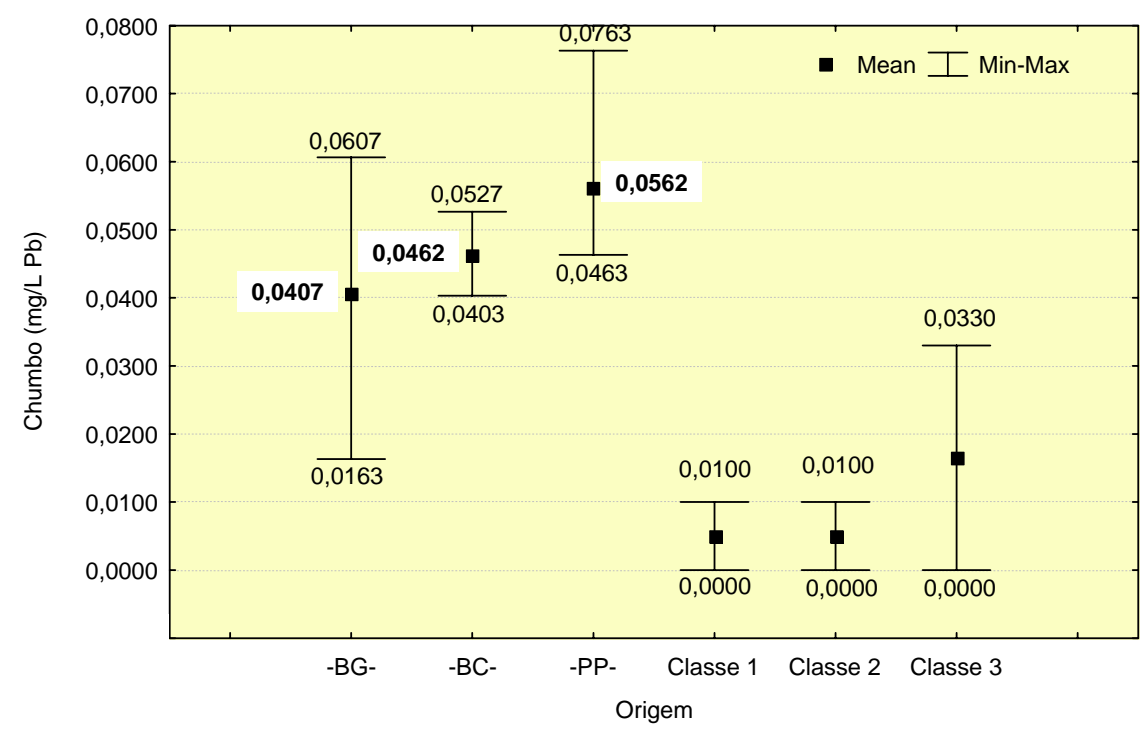

Figura 24 - Gráfico da variação da concentração de chumbo e comparação com a classificação preconizada pela Resolução CONAMA 357/05.

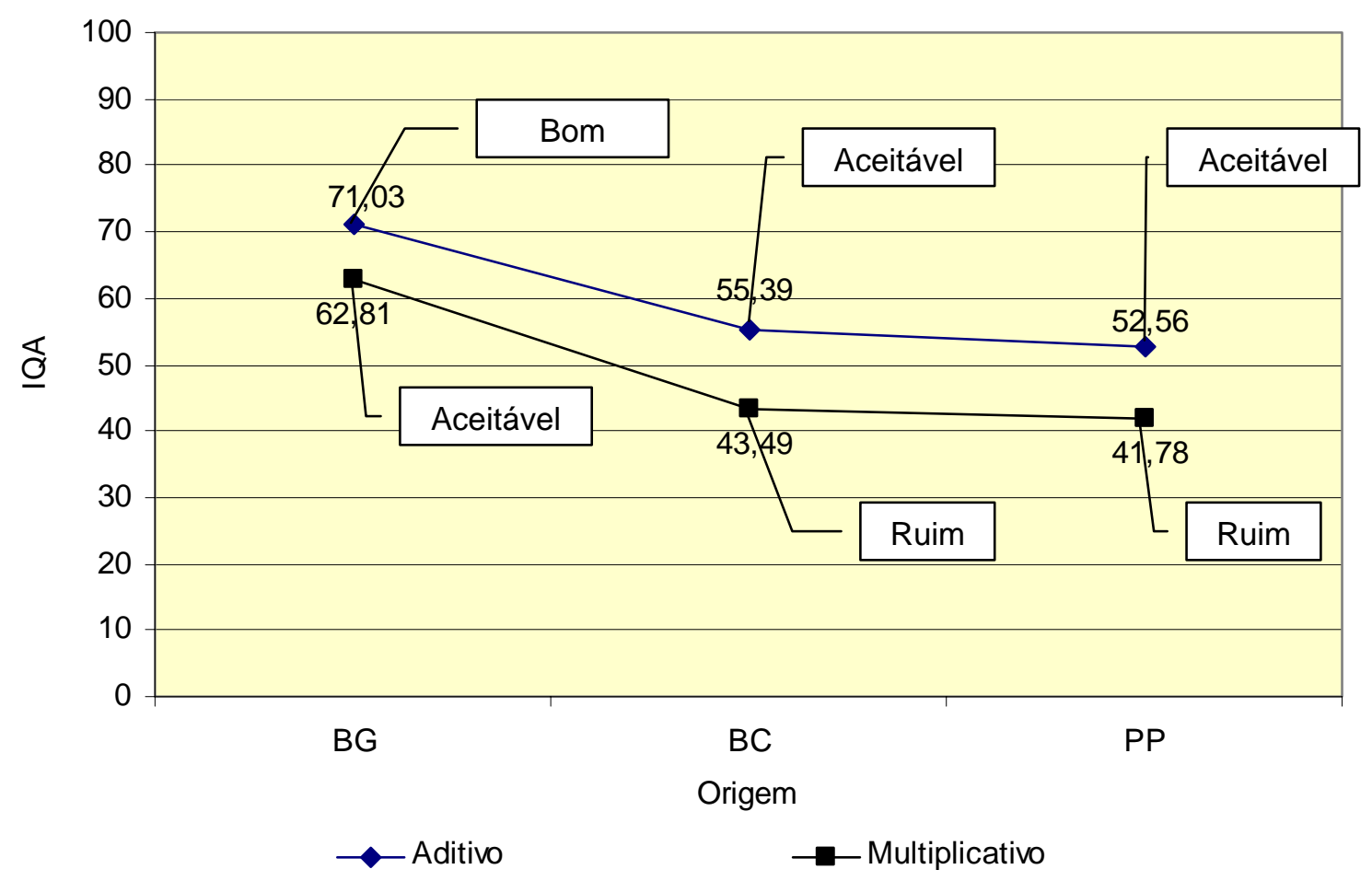

Figura 25 - Gráfico da variação do Índice de Qualidade de Águas (IQA) ao longo do Rio Mossoró.

\section{CONCLUSÃO}

Após a análise dos resultados e as comparações com os padrões preconizados pela Resolução CONAMA n $\mathrm{n}^{\circ} .357$, de 17 de março de 2005, que dispõe sobre a classificação dos corpos de água e diretrizes ambientais para o seu enquadramento, pode-se tirar as seguintes conclusões:

- Como esperado, a sazonalidade climática exerce grande influência sobre as concentrações das variáveis consideradas, e a contaminação tende a aumentar no sentido montantejusante da cidade; 
- Os resultados de coliformes termotolerantes são aqueles que merecem maior atenção, pois todos os pontos apresentaram concentrações superiores ao limite preconizado para Classe 3. Resultado preocupante, pois, como observado durante a coleta, as pessoas tomam banho, lavam roupas e etc. no rio, estando sujeitos a diversas enfermidades (Tabela 1);

- Quanto à cor, deve-se atentar para os valores elevados na localidade Barragem Central e Passagem de Pedra (Classe 2 e 3). Caso a água do rio passe a ser utilizada para abastecimento humano, a técnica de tratamento deverá atentar para a formação de trialometanos, produtos carcinogênicos da desinfecção das águas;

- Referente ao oxigênio dissolvido, os pontos foram classificados como Classe 1. No entanto deve-se ressaltar que BG e PP apontam para o fenômeno da eutrofização (OD acima da saturação e elevada concentração de algas e macrófitas) em algumas amostras. Esse fenômeno é influenciado pela construção das próprias barragens que afetam as características dos corpos aquáticos, no caso Rio Mossoró, diminuindo seu caráter lótico (água corrente) e aumentando o caráter lêntico (água parada).

- Relativo ao chumbo, único metal Classe 3, é necessário uma avaliação específica no sentido de identificar os possíveis fatores contribuintes (naturais ou antrópicos) para as altas concentrações.

Por fim, o cálculo do Índice de Qualidade - IQA pelo método multiplicativo mostrou-se mais restritivo e, em conseqüência, mais sensível para refletir valores de qualidade mais baixa em relação aos diferentes parâmetros. Assim, comenta-se aqui o IQA multiplicativo que demonstra a classificação na faixa do Aceitável $(50<$ IQA $\leq 70)$ para Barragem do Genésio, enquanto que a Barragem Central e Passagem de Pedra se encaixam na faixa Ruim $(25<$ IQA $\leq 50)$.

\section{REFERÊNCIAS}

AGÊNCIA NACIONAL DAS ÁGUAS. Atlas Nordeste: Abastecimento Urbano de Água. Disponível: < http://parnaiba.ana.gov.br/atlas_nordeste/down/ATLAS_NORD ESTE.pdf >. Acesso em: 10 mar. 2007.

AMARAL, Luiz Augusto; FILHO, Antonio Nader; JUNIOR, Oswaldo Durival Rossi; FERREIRA, Fernanda Lúcia Alves; BARROS, Ludmilla Santana Soares. Água de consumo humano como fator de risco à saúde em propriedades rurais. Rev. Saúde Pública., São Paulo, v. 37, $\quad$ n. $4, \quad 2003.4003$ Disponível $<$ http://www.scielo.br/scielo.php?script=sci_arttext\&pid=S0034-89102003000400017 $\& \operatorname{lng}=$ pt\&nrm=iso $>$. Acesso em: 13 fev 2007.

AMERICAN PUBLIC HEALTH ASSOCIATION (APHA), AMERICAN WATER WORKS ASSOCIATION (AWWA), WATER ENVIROMENT FEDERATION (WEF). Standard Methods for the Examination of Water and Wastewater. 1992.

. Standard Methods for the Examination of Water and Wastewater. 1995.

ARAÚJO, A. L. C.; DOS SANTOS, J. P. Relatório de Análises de Água (Rio Mossoró Mossoró-RN). Centro Federal de Educação Tecnológica do Rio Grande do Norte. Laboratório de Análises de Águas e Efluentes. Natal. 2005.

BAPTISTA, Gustavo Macedo de Mello; CARVALHO, José Maria; CAMACHO, Ramiro Gustavo Valera; BIAS, Edilson de Souza; ZARA, Luiz Fabrício. Variação Sazonal da 
Vegetação e da Temperatura de Superfície em Mossoró/RN, por Meio de Dados ASTER. Anais XII Simpósio Brasileiro de Sensoriamento Remoto. Goiânia. 2005. Disponível em: $<$ http://marte.dpi.inpe.br/col/ltid.inpe.br/sbsr/2004/ 11.19.22.27/doc/2843.pdf $>$. Acesso em: 23 out. 2006.

CARVALHO, Sérgio Luís. Eutrofização Artificial: Um Problema em Rios, Lagos e Represas. Correio de Três Lagoas, Três Lagoas/MS, ago. 2004 Disponível em: $<$ http://www.agr.feis.unesp.br/ctl2808 2004.php>. Acesso em: 10 mar. 2007.

CARVALHO, Cornélio de Freitas; FERREIRA, Adalberto Luiz; STAPELFELDT, Frank. Qualidade das águas do ribeirão Ubá - MG. Rem: Rev. Esc. Minas., Ouro Preto, v. 57, n. 3, 2004. Disponível em: <http://www.scielo.br/scielo.php? script=sci_arttext\&pid=S037044672004000300005\&lng=en\&nrm=iso>. Acesso em: 09 Mar 2007.

CASTILHOS, Danilo Dufech; COSTA; Claudia das Neves; PASSIANOTO; Caio César; LIMA; Ana Claudia Rodrigues; LIMA; Claudia Liane Rodrigues; MULLER; Valberto; Adição de cromo hexavalente no crescimento, nodulação e absorção de nutrientes em soja. Ciência Rural., Santa Maria, v. 31, n. 6, 2001. Disponível em: $<$ http://www.scielo.br/scielo.php?script=sci_arttext\&pid=S0103-8478200100060 0008\&lng=pt\&nrm=iso $>$. Acesso em: 10 fev. 2007.

COMPANHIA DE TECNOLOGIA DE SANEAMENTO AMBIENTAL (CETESB). Variáveis de Qualidade das Águas. São Paulo. 2006. Disponível em: < http://www.cetesb.sp.gov.br/Agua/rios/variaveis.asp>. Acesso em: 23 out. 2006.

IQA - Índice de qualidade das águas. São Paulo. 2006. Disponível em:

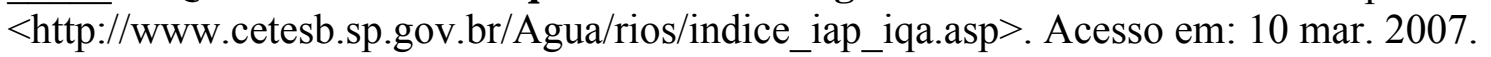

CONSELHO NACIONAL DO MEIO AMBIENTE (CONAMA). Resolução no 274 de 29 de novembro de 2000. Dispõe sobre a balneabilidade.

CONSELHO NACIONAL DO MEIO AMBIENTE (CONAMA). Resolução no 357 de 17 de março de 2005. Dispõe sobre a classificação dos corpos de água e diretrizes ambientais para o seu enquadramento, bem como estabelece as condições e padrões de lançamento de efluentes. Ministério do Meio Ambiente. 2005.

COSTA, Luciana de Luna; CEBALlOS, Beatriz S. O.; MEIRA, Celeide M. B. S.; CAVALCANTI, Mário Luiz Farias. Eficiência de Wetlands construídos com dez dias de detenção hidráulica na remoção de colífagos e bacteriófagos. Revista de Biologia e Ciências da Terra. Vol. 3, $\mathrm{n}^{\mathrm{o}}$ 1. 2003. Disponível em: $<$ http://www.uepb.edu.br/eduep/rbct/sumarios/pdf/wetlands.pdf $>$. Acesso em: $<6$ mar. 2007.

CUNHA, Cynara de Lourdes da Nóbrega; FERREIRA, Aldo Pacheco. Mathematical modeling to assess the effects of organic waste dumping on sanitary conditions of environmental waters. Cad. Saúde Pública., Rio de Janeiro, v. 22, n. 8, 2006. Disponível em: $\quad<$ http://www.scielo.br/scielo.php?script=sci_arttext\&pid =S0102311X2006000800020\&lng=en\&nrm=iso>. Acesso em: 09 mar. 2007.

DINIZ, Ronaldo Fernandes (coord.). Estudo Balneabilidade das Praias do Estado do Rio Grande do Norte. Centro Federal de Educação Tecnológica do Rio Grande do Norte, 
Instituto de Desenvolvimento Econômico e Meio Ambiente do Rio Grande do Norte, Fundação de Apoio à Educação e ao Desenvolvimento Tecnológico do Rio Grande do Norte. 2006. Disponível em: < http://www.cefetrn.br/programaaguaviva/h pprograma.htm>. Acesso em: 23 out. 2006.

ENVIRONMENTAL PROTECTION AGENCY (EPA). Drinking Water Contaminants. Disponível em: $<$ http://www.epa.gov/safewater/contaminants/index.html\#inorganic $>$. Acesso em: 10 mar. 2007.

FEDERAÇÃO DAS INDÚSTRIAS DO ESTADO DO RIO GRANDE DO NORTE (FIERN). Estudo de Oportunidades Econômicas para Mossoró. In: Produtos e serviços. 199-?. Disponível em: <http://www.fiern.org.br/servicos/estudos/mossoro/ mossoro2/index.htm>. Acesso: 10 mar. 2007.

Plano Diretor de Mossoró. In: Produtos e serviços. 199-?. Disponível em: $<\mathrm{http}$ ://www.fiern.org.br/servicos/estudos/mossoro/mossoro2/pdiretor.htm>. Acesso: 10 mar. 2007.

FERREIRA, Douglisnilson de Moraes. Avaliação do índice da Qualidade da Água da Escola Agrícola de Jundiaí. Natal, 2006.

GIANNETTI, B.F.; ALMEIDA. C.M.V.B.; BONILLA, S.H.; VENDRAMETO, O. Nosso Cromo de Cada Dia: Benefícios e Riscos. Revista de Graduação da Engenharia Química ANO IV nº. 8 jul-dez 2001. ISSN 1516-5469.

INSTITUTO BRASILEIRO DE GEOGRAFIA E ESTATÍSTICA (IBGE). CENSO 2000. Brasil. 2005.

JESUS, Carlos Antônio Gonçalves de. Balanço Mineral Brasileiro 2001. Departamento Nacional de Produção Mineral (DNPM). Disponível em: $<$ http://www.dnpm.gov.br/assets/galeriadocumento/balancomineral2001/zinco.pdf $>$. Acesso em: 11 fev. 2007.

JORNAL DE FATO. Mossoró é o seu Rio. Secretaria de Estado dos Recursos Hídricos (SERHID). 2005. Disponível em: <http://www.serhid.rn.gov.br/detalhe.asp? IdPublicacao $=5488>$. Acesso em: 12 out. 2006.

JORNAL O MOSSOROENSE. Saneamento básico atende $\mathbf{5 5 \%}$ da população de Mossoró. 2007. Disponível em: <http://www.semarh.rn.gov.br/detalhe.asp?IdPubli cacao=7136>. Acesso em: 10 mar. 2007.

MANASSARAM, Deana M.; BACKER, Lorraine C.; MOLL, Deborah M. A review of nitrates in drinking water: maternal exposure and adverse reproductive and developmental outcomes. Ciênc. Saúde Coletiva, mar 2007, vol.12, $\mathrm{n}^{\mathrm{o}} .1, \mathrm{p} .153-163$. ISSN $1413-8123$.

MARSOLA, Tatiana; MIYAZAWA, Mario; PAVAN, Marcos A.. Accumulation of copper and zinc in the snap bean tissues in relation to that extracted from the soil. Rev. Bras. Eng. Agríc. Ambient., Campina Grande, v. 9, n. 1, 2005. Disponível em: 
$<$ http://www.scielo.br/scielo.php?script=sci_arttext\&pid=S1415-

43662005000100014\&lng=en\&nrm=iso>. Acesso em: 10 Mar 2007.

MOREIRA, Fátima Ramos; MOREIRA, Josino Costa. A cinética do chumbo no organismo humano e sua importância para a saúde. Ciênc. Saúde coletiva, 2004, vol.9, nº.1, p.167181. ISSN 1413-8123.

MORGANO, Marcelo A.;GOMES, Priscila C.; MANTOVANI, Dilza M. B.; PERRONE, Adriana A. M.; SANTOS; Talita F. Níveis de mercúrio total em peixes de água doce de pisciculturas paulistas. Ciênc. Tecnol. Aliment., abr./jun. 2005, vol.25, $\mathrm{n}^{\mathrm{o}} .2$, p.250-253. ISSN 0101-2061.

OLIVEIRA, Juraci Alves; CAMBRAIA, José; CANO, Marco Antonio Oliva; JORDÃO, Cláudio pereira. Absorção e acúmulo de cádmio e seus efeitos sobre o crescimento relativo de plantas de aguapé e de salvínia. Rev. Bras. Fisiol. Veg., 2001, vol.13, nº.3, p.329-341. ISSN 0103-3131.

PÁDUA, Helcias Bernardo. O cuidado com as águas. In: Série: Águas Especiais. Mato Grosso do Sul, $\mathrm{n}^{\mathrm{o}}$. 4. 2003. Disponível em: <http://www.bonitoms.com.br/site/noticias1.asp?id=24>. Acesso em: 10 mar. 2007.

PONTES, Carlos Antonio Alves; SCHRAMM, Fermin Roland. Bioética da proteção e papel do Estado: problemas morais no acesso desigual à água potável. Cad. Saúde Pública, Rio de Janeiro, v. 20, n. 5, 2004. Disponível em: $<$ http://www.scielo.br/scielo.php?script=sci_arttext\&pid=S0102-311X2004000500026 $\& \operatorname{lng}=$ pt\&nrm=iso>. Acesso em: 13 fev. 2007.

QUITERIO, Simone Lorena; MOREIRA, Fátima Ramos; SILVA, Célia Regina Sousa; ARBILLA, Graciela; ARAÚJO, Ulisses César; MATTOS, Rita de Cássia O. da C. Avaliação da poluição ambiental causada por particulado de chumbo emitido por uma reformadora de baterias na cidade do Rio de Janeiro, Brasil. Cad. Saúde Pública, set. 2006, vol.22, $\mathrm{n}^{\mathrm{o}} .9, \quad \mathrm{p} .1817-1823$. ISSN 0102-311X. Disponível em: $<$ http://www.scielo.br/pdf/csp/v22n9/05.pdf>. Acesso em: 13 fev. 2007.

RAMOS, Luiz Antônio; CAVALHEIRO, Carla Cristina Schmitt; CAVALHEIRO, Éder Tadeu Gomes. Determination of nitrite in water using a flower extract. Quím. Nova., São Paulo, v. 29, n. 5, 2006. Disponível em: <http://www.scielo.br/scielo. php?script $=$ sci_arttext\&pid $=\mathrm{S} 0100-40422006000500037 \& \operatorname{lng}=\mathrm{en} \& \mathrm{nrm}=\mathrm{iso}>$. Acesso em: 10 mar. 2007.

SECRETARIA DE ESTADO DO MEIO AMBIENTE E DOS RECURSOS HÍDRICOS (SEMARH). Mapa: Bacia Hidrográfica do Apodi-Mossoró. Disponível em: <http: //www.semarh.rn.gov.br/consulta/cBaciaDetalhe.asp?CodigoEstadual=01>. Acesso em: $12 \mathrm{de}$ mar. 2007.

SERVIÇOS GEOLÓGICO DO BRASIL (CPRM). Diagnóstico do Município de Mossoró. Set. 2005. Disponível em: <http://www.cprm.gov.br/rehi/atlas/rgnorte/ relatorios/MOSS089.PDF> . Acesso em: 10 mar. 2007. 
SILVA, Gilberto Silvério; JARDIM, Wilson de F. A new water quality index for protection of aquatic life appllied to the Atibaia River, region of Campinas/Paulínia cities - São Paulo State. Quím. Nova., São Paulo, v. 29, n. 4, 2006. Disponível em: $<$ http://www.scielo.br/scielo.php?script=sci_arttext

$40422006000400012 \& \operatorname{lng}=$ en\&nrm=iso $>$. Acesso em: 10 mar. 2007.

\&pid=S0100-

SIQUEIRA, Gilmar Wanzeller; BRAGA, Elisabete de Santis; PEREIRA, Simone de Fátima Pinheiro; SILVA, Elisamar. Distribuição do mercúrio em sedimentos de fundo no Estuário de Santos SP/Brasil. Rem: Rev. Esc. Minas, out./dez. 2005, vol.58, nº.4, p.309316. ISSN 0370-4467.

TUNDISI, José Galizia. O Futuro dos Recursos: Recursos Hídricos. Rev. MultiCiência.. São Paulo, $\mathrm{n}^{\circ}$. 1, art. 3. Out. 2003. Disponível em: < http://www.multiciencia.unicamp.br/artigos_01/A3_Tundisi_port.PDF $>$. Acesso em: 10 mar. 2007.

VALENTE, José Pedro Serra; PADILHA, Pedro Magalhães; SILVA, Assunta Maria Marques. Oxigênio dissolvido (OD), demanda bioquímica de oxigênio (DBO) e demanda química de oxigênio (DQO) como parâmetros de poluição no ribeirão Lavapés/Botucatu - SP. Eclet. Quím. 1997, São Paulo. Disponível em: $<$ http://www.scielo.br/scielo.php?script=sci_arttext\&pid=S0100-4670199700010000

$5 \& \operatorname{lng}=$ pt\&nrm $=$ iso $>$. Acesso em: 10 mar. 2007.

VIANA, Guarany Marques. Sistemas Públicos de Abastecimento de Água. João Pessoa, 1997.

SPERLING, Marcos Von. Introdução à Qualidade das Águas e ao Tratamento de Esgotos. 2 ed. Belo Horizonte: Departamento de Engenharia Sanitária e Ambiental; Universidade Federal de Minas Gerais, 1996. 